Revista de Biología Marina y Oceanografía

Vol. 52, N³: 591-610, diciembre 2017

DOI 10.4067/S0718-19572017000300015

ARTICLE

\title{
A bloom of Azadinium polongum in coastal waters off Peru
}

\author{
Floración de Azadinium polongum en aguas costeras del Perú
}

\section{Urban Tillmann ${ }^{1 *}$, Sonia Sánchez-Ramírez ${ }^{2}$, Bernd Krock¹ and Avy Bernales-Jiménez²}

\begin{abstract}
${ }^{1}$ Alfred Wegener Institute for Polar and Marine Research, Am Handelshafen 12, D-27570 Bremerhaven, Germany. *urban.tillmann@ awi.de ${ }^{2}$ Laboratorio de Fitoplancton y Producción Primaria, IMARPE, Esquina Gamarra y Gral. Valle s/n Chucuito, Callao, Perú

Resumen.- Las especies dinofíceas del género Azadinium son conocidas por la producción potencial de azaspirácidos (AZAs), un grupo de toxinas microalgales que pueden causar intoxicación a través de mariscos. El incremento de registros globales de Azadinium indican una distribución bastante amplia de este género, sin embargo los datos cuantitativos de abundancia de las especies de familia Amfidomataceae son difíciles de encontrar. Como parte del programa de monitoreo bio-oceanográfico en aguas costeras peruanas frente a Chancay, se detectó y muestreó en febrero de 2014 una floración densa de Azadinium, con una temperatura de agua de mar alrededor de $20,5{ }^{\circ} \mathrm{C}$ y una salinidad de 35 . Este es el primer reporte de una floración de Azadinium en el océano Pacífico con densidades celulares de hasta un millón de células por litro causante de una decoloración del agua de mar. Usando microscopía electrónica de barrido, se determinó como taxón responsable a Azadinium polongum. Esta especie previamente había sido detectada sólo en las Islas Shetland (Atlántico norte), localidad tipo y descrita como no productora de AZA. La población observada en campo se ajustó al cultivo tipo Shetland en la mayoría de los aspectos morfológicos. Sin embargo, a diferencia de este tipo de cultivo de Az. polongum, la primera placa intercalar de la población observada en el Pacífico, en ningún caso, estuvo en contacto con la primera placa precingular. Más aún, el tamaño y la forma de la segunda placa intercalar fue ligeramente diferente y muy variable en la población del Pacífico, ocurriendo en casi igual abundancia en configuración cuadra (es decir, en contacto con cuatro placas) o configuración penta (en contacto con cinco placas), un rasgo no reportado para el cultivo tipo de Az. polongum. La cromatografía líquida acoplada con espectrometría de masa no detectó AZA por encima del nivel de detección en la muestra de la floración, indicando que la especie peruana de Az. polongum puede considerarse como no productora de AZA.
\end{abstract}

Palabras clave: Floración algal, Azadinium, Perú

\begin{abstract}
Species of the dinophycean genus Azadinium are known for their potential production of azaspiracids (AZAs), a group of microalgal toxins that can cause shellfish poisoning. Increase of global Azadinium records indicates a rather wide distribution, but quantitative abundance data of species of Amphidomataceae are hardly available. Within the Peruvian bio-oceanographic monitoring program we detected and sampled a dense bloom of Azadinium in Peruvian coastal waters off Chancay in February 2014 at a water temperature of about $20.5^{\circ} \mathrm{C}$ and a salinity of 35 . With water discoloration and cell densities of Azadinium up to 1 million cells per liter this is the first Azadinium bloom record for the Pacific. The causative taxon was determined using scanning electron microscopy as Azadinium polongum, a species previously recorded only from the type locality, the Shetland Islands (north Atlantic) and described as non-AZA producer. The field population conformed to the Shetland type culture in most morphological aspects. However, the first intercalary plate of the Pacific field population without exception was not in contact with the first precingular plate, which is different to the type culture of Az. polongum. Moreover, the size and shape of the median intercalary plate was slightly different and very variable in the Pacific population, and occurred in about equal abundance in quadra- (i.e., in contact with four other plates) or in penta-configuration (i.e., in contact with five other plates), a feature not reported for the type culture of Az. polongum. Liquid chromatography coupled with mass spectrometry revealed no AZA above detection level in the bloom sample, indicating that the Peruvian Az. polongum can be regarded as a non-AZA producer.
\end{abstract}

Key words: Algal bloom, Azadinium, Peru

\section{INTRODUCTION}

The Humboldt Current flowing along the west coast of South America is one of the major systems of the world, where cold, nutrient-rich upwelling water drives extraordinarily high rates of primary and secondary productivity. Especially off the coast of Peru, upwelling occurs year round sustaining large fish stocks of mainly anchovy [Engraulis ringens (Jenyns, 1842)] and other species such as jack mackerel [Trachurus murphyi (Nichols, 1920)] and chub mackerel [Scomber japonicus (Houttuyn, 
1782)], thus making marine fisheries a key component of Peru's economy (Sánchez 2000). During strong upwelling periods occurring typically in winter and spring, diatoms dominate the system, whereas dinoflagellates and other smaller sized flagellates are found during relaxation periods typically in summer and autumn (Ochoa et al. 2010). Diatoms are known to support a high and efficient food web transfer of primary production to fish (Cushing 1989). In contrast, many Dinophyceae or other planktonic flagellates are known for the production of potent toxins and other bioactive compounds and may form Harmful Algal Blooms (HABs) causing human health problems, massive killing of fishes, birds or mammals, and/or other ecosystem disruptions (Smayda 1997, Hallegraeff 2003, 2014).

Reports of HABs for the Humboldt Current system are most common off central Peru where red tides have been linked to fish and bird mortalities since the early 1800s (Trainer et al. 2010). High biomass blooms often accompanied by water discoloration (locally known as 'aguajes') and anoxia were mainly due to blooms of Akashiwo sanguinea (K.Hirasaka) G.Hansen \& Moestrup (as Gymnodinium splendens Lebour) (Rojas de Mendiola 1979) in the 1970s and also Prorocentrum Ehrenberg (Prorocentrum micans Ehrenberg, Prorocentrum gracile Schütt) and Tripos Bory (Tripos furca (Ehrenberg) F. Gómez, Tripos fusus (Ehrenberg) F.Gómez) in the following decades (Sánchez \& Delgado 1996). In recent years there is cumulating evidence on the presence of dinoflagellate species which produce toxins, including species of Dinophysis Ehrenberg and Alexandrium Halim (Ochoa et al. 2010, Trainer et al. 2010). Paralytic shellfish poisoning (PSP) caused by saxitoxin and its derivatives is one of the major concerns worldwide (Anderson et al. 2012), and a first record of PSP toxins in Peruvian shellfish was reported in 2003 (Antinori et al. 2003). Alexandrium peruvianum (Balech \& Mendiola) Balech \& Tangen, now considered synonym of Alexandrium ostenfeldii (Paulsen) Balech \& Tangen (Kremp et al. 2014), was described as Gonyaulax peruviana Balech \& B.R.E. de Mendiola from Callao (Peru), where red tides of the species occurred (Rojas de Mendiola 1979, Sánchez et al. 2004¹). More recently, other species of Alexandrium were reported in the area for the first time, including Alexandrium affine (H.Inoue \& Y.Fukuyo) Balech (Vera et al. 1999), and the potentially toxic species Alexandrium tamiyavanichi Balech (Bárcena-Martínez et al. 2013) and Alexandrium minutum Halim (Baylón et al. 2015).
For these large and conspicuous species it is difficult to evaluate if they have been recently introduced to the area or if they - as low abundance background species - had been overlooked previously. A plankton species list of the Peruvian coastal waters included a total of 208 dinoflagellate species (Ochoa et al. 1999) with the majority of species assigned to two large and conspicuous thecate generic lineages Tripos (as Ceratium) and Protoperidinium R.S. Bergh. However, biodiversity and distribution of the smaller size class of plankton species most probably has not been fully explored in the past, as identification of smaller and less conspicuous dinophytes is quite difficult and in many cases requires electron microscopy. An illustrative example is the small dinophycean genus Azadinium Elbrächter \& Tillmann (Amphidomataceae). This taxon was discovered in 2009 driven by the targeted search for the planktonic source of azaspiracids (AZAs) (Krock et al. 2009) with the first species described being Azadinium spinosum Elbrächter \& Tillmann (Tillmann et al. 2009). AZAs are a group of lipophilic marine biotoxins associated with human incidents of shellfish poisoning. This group of compounds was first isolated and identified 18 years ago from Irish shellfish (Satake et al. 1998) but now has been reported from numerous geographical sites, including the Pacific coast of the United States (Trainer et al. 2013), and both the Atlantic and Pacific coasts of South America with records from Brazil (Massucatto et al. 2014), Argentina (Turner \& Goya 2015), and Chile (Álvarez et al. 2010, López-Rivera et al. 2010).

The knowledge on the diversity of Azadinium has increased rapidly and today eleven species have been described (Tillmann \& Akselman 2016). Within the genus Azadinium, three species have been found to produce AZAs (i.e., Azadinium spinosum, Azadinium poporum Tillmann \& Elbrächter, Azadinium dexteroporum I.Percopo \& A.Zingone (Krock et al. 2012, Rossi et al. 2017). AZAs have also been found in the related species Amphidoma languida Tillmann, Salas \& Elbrächter (Tillmann et al. 2012b).

Just as for records of AZA in shellfish there is increasing evidence that species of Azadinium and Amphidoma F.Stein seem to have a wide geographical distribution in both coastal and open ocean areas of Atlantic and Pacific Oceans (Tillmann \& Akselman 2016). Records from the Pacific include Korea (Potvin et al. 2012), China (Gu et al. 2013, Luo et al. 2013), New Zealand (Smith et al. 2016), and recently also northern Chile (Tillmann et al. 2017).

\footnotetext{
${ }^{1}$ Sánchez S, P Villanueva \& L Carbajo. 2004. Distribution and concentration of Alexandrium peruvianum (Balech and de Mendiola) in the Peruvian coast $\left(03^{\circ} 24^{\prime}-18^{\circ} 20^{\prime}\right.$ LS) between 1982-2004. In: Abstracts, XI International Conference on Harmful Algal Blooms, Cape Town, South Africa, November 15-19, 2004: p. 227
} 
Knowledge on the occurrence and distribution of species is quite patchy and incomplete, and quantitative abundance data of Amphidomataceae are hardly available. Nevertheless, they have the potential to form dense blooms, as has been observed for a species of Azadinium from the Argentinean shelf almost 25 years ago (Akselman \& Negri 2012). One of these old Argentinean bloom populations has retrospectively been identified to represent a quite diverse assemblage of different species of Azadinium and Amphidoma (Tillmann \& Akselman 2016). Also related to South America, toxic isolates of $A z$. poporum were recently obtained from the south Atlantic (Argentina: Tillmann et al. 2016) and from the northern part (Gulf of Mexico: Luo et al. 2016). On the Pacific side of South America, there has been only one record of a species determined as Az. spinosum, from the coast of Mexico (Hernández-Becerril et al. 2012).

In January and February of 2014 stranding of different dead animal species, such as the small crustacean Emerita analoga (Stimpson, 1857), the bivalve Semimytilus algosus (Gould, 1859), the crab Platyxanthus orbignyi (H.Milne Edwards \& Lucas, 1843) and the anchovy Engraulis ringens, was observed along the central Peruvian coast line. These incidents prompted Instituto del Mar del Perú - IMARPE to implement the plankton survey 'Bio-oceanographic monitoring in the marine coastal area between Chancay and Supe' during February 2014 , in order to search for the causes of these animal mortalities. During this monitoring a dense bloom of Azadinium in Peruvian coastal waters off Chancay was detected and sampled. This bloom was accompanied by water discoloration. As some species of Azadinium are known to produce azaspiracid toxins it was the aim of the present study to record the environmental settings of this bloom and to more specifically analyse the presence of AZA, as well as to identify the causative species.

\section{Materials AND METHODS}

\section{SAMPLING}

A total of 11 stations located between 4 and 10 nautical miles off the shoreline were sampled (Fig. 1). Water transparency was estimated using a Secchi disc. At each station surface water samples (taken with a bucket) and water samples from $10 \mathrm{~m}$ depth (taken with a 5 L Niskin bottle sampler) were obtained. Temperature and salinity of these samples were determined with a SBE 19plus CTD (Sea-Bird Electronics). From each water sample $80 \mathrm{~mL}$ were fixed with buffered formalin ( $2 \%$ final concentration) for quantitative plankton analysis. At station 2 where suspicious plankton densities were observed, one liter from surface and another from $20 \mathrm{~m}$ depth samples were collected on filters (GF/C, $25 \mathrm{~mm}$ diameter, Whatman). Filters were stored frozen in liquid nitrogen at $-80^{\circ} \mathrm{C}$ until they were shipped for azaspiracid analysis to Germany.

\section{Analysis}

OXYGEN, NUTRIENTS, CHLOROPHYLL, AND WIND ANALYSIS

The following parameters were estimated from the water samples: Dissolved oxygen using a modified Winkler method (Carrit \& Carpenter 1966); dissolved inorganic nutrients $\left(\mathrm{NO}_{3}\right.$, $\mathrm{NO}_{2}, \mathrm{PO}_{4}, \mathrm{SiO}_{4}$ ) according to Strickland \& Parsons (1972) and UNESCO (1983) by using an Perkin Elmer Lambda 40 spectrophotometer; and chlorophyll according to the fluorometric approach of Holm-Hansen et al. (1965) using a Turner Designs 10 AU Fluorometer.

Upwelling dynamics between 1 and 13 February 2014 were evaluated using the wind satellite information obtained by the ASCAT scatterometer and the resulting Hovmöller diagrams from wind intensity and speed anomalies. The coastal upwelling index (Bakun and Parrish 1982) along $40 \mathrm{~km}$ of the Peruvian coastal line $\left(9^{\circ}\right.$ to $\left.12^{\circ} \mathrm{S}\right)$ was analyzed.

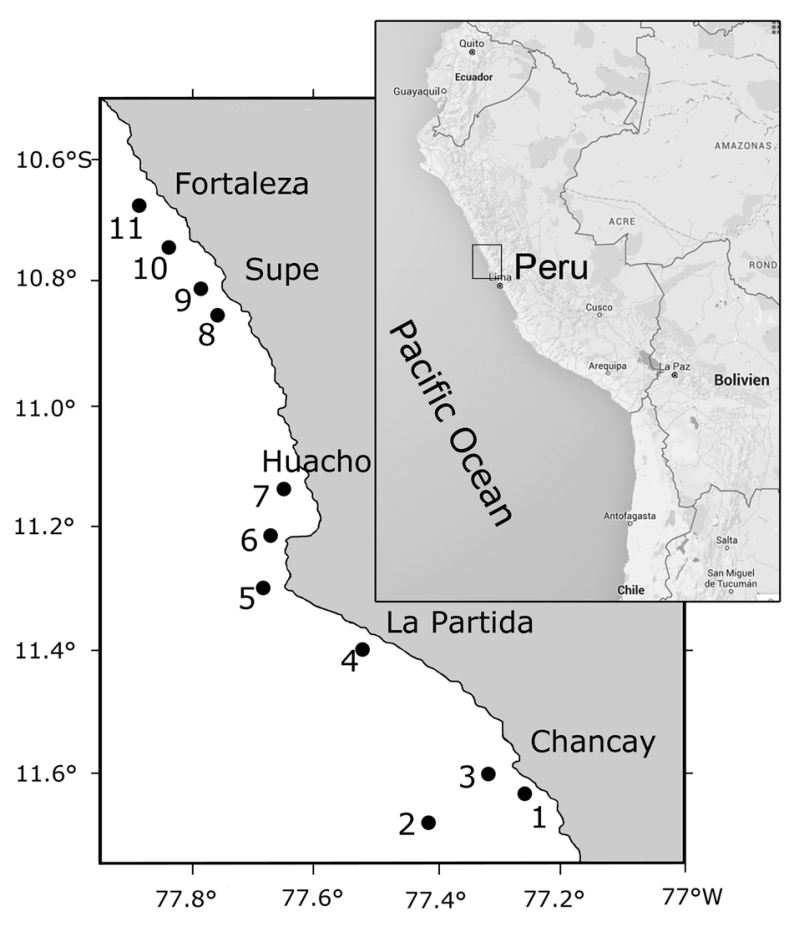

Figure 1. Study area and location of sampling sites along the Peruvian coast / Área de estudio y ubicación de estaciones de muestreo a lo largo de la costa peruana 
The spatial resolution of this information is $\sim 25 \mathrm{~km}$ and the frequency is daily. The information is stored in binary files of structured type and metadata (called, NetCDF files). Wind information of ASCAT satellite is freely accessible and can be obtained from the following link <ftp://ftp.ifremer.fr/ifremer/ cersat/> (Source: ASCAT, prepared by Santa Rosa Coastal Laboratory and the Marine Hydrophysics Laboratory, IMARPE).

\section{Plankton analysis}

Quantitative plankton analyses were performed using the sedimentation technique (Karlson et al. 2010), in $50 \mathrm{~mL}$ chambers, sedimented over 24 hours. The analysis was performed with an inverted microscope (NIKON ECLIPSE TE 300). Abundant species and species less than $50 \mu \mathrm{m}$ were counted on a longitudinal transect with $500 \mathrm{x}$ magnification (corresponding to a sample volume of $0.61 \mathrm{~mL}$ ), and less abundant and larger organisms $(>50 \mu \mathrm{m})$ species were counted in the whole chamber with $125 \mathrm{x}$ magnification. Results are expressed as cells $\mathrm{L}^{-1}$. Photographs were taken with a digital camera 5.0 MP (Novel Optics, HDCE Series) connected to a compound microscope (NIKON ECLIPSE E400) using software Scope Image 9.0.

\section{ELECTRON MICROSCOPY}

For station 2, a detailed scanning electron microscope (SEM) analysis was performed to determine the causative species of a dense bloom of a small dinophyte. For this purpose, $30 \mathrm{~mL}$ formalin-fixed bottle samples from 0 and $10 \mathrm{~m}$ depth were concentrated to a combined final volume of $2 \mathrm{~mL}$ by sedimentation. Subsamples were subsequently collected on polycarbonate filters (Millipore, $25 \mathrm{~mm} \varnothing, 3 \mu \mathrm{m}$ pore-size) in a filter funnel where all subsequent washing and dehydration steps were carried out. Eight washings ( $2 \mathrm{~mL}$ MilliQ-deionized water each) were followed by a dehydration series in ethanol (30, 50, 70, 80, 95 and 100\%; 15 min each). Filters were dehydrated with hexamethyldisilazane(HMDS), initially 1:1 HMDS:EtOH followed by $2 \times 100 \% \mathrm{HMDS}$, and stored under gentle vacuum in a desiccator. Finally, filters were mounted on stubs, sputtercoated with gold-palladium (Emscope SC500, Ashford, UK) and viewed under a SEM (FEI Quanta FEG 200, Eindhoven, the Netherlands). SEM micrographs were presented on a black background using Adobe Photoshop 6.0 (Adobe Systems, San Jose, California, USA)

\section{Analysis of aZASPIRACIDS}

\section{EXTRACTION FROM FILTERS}

Glass fiber filters were transferred into cryovials containing 0.9 g lysing matrix D (Thermo Savant, Illkirch, France) and subsequently homogenized in $500 \mu \mathrm{L}$ methanol by two times reciprocal shaking at maximum speed $\left(6.5 \mathrm{~m} \mathrm{~s}^{-1}\right)$ for $45 \mathrm{~s}$ in a Bio101 FastPrep instrument (Thermo Savant, Illkirch, France). After homogenization, samples were centrifuged at $16,100 \mathrm{x} g$ at $4{ }^{\circ} \mathrm{C}$ for $15 \mathrm{~min}$. The supernatants were transferred to spinfilters $(0.45 \mu \mathrm{m}$ pore-size, Millipore Ultrafree, Eschborn, Germany) and centrifuged for $30 \mathrm{~s}$ at $800 \mathrm{x}$ g. Filtrates were transferred to autosampler vials for analysis by liquid chromatography coupled tandem mass spectrometry (LC-MS/ MS).

\section{SingLe REACTION MONITORING (SRM) MEASUREMENTS}

Water was deionized and purified (Milli-Q, Millipore, Eschborn, Germany) to $18 \mathrm{M} \Omega \mathrm{cm}^{-1}$ or better quality. Formic acid $(90 \%$, p.a.), acetic acid (p.a.) and ammonium formate (p.a.) were purchased from Merck (Darmstadt, Germany). The solvents, methanol and acetonitrile, were high performance liquid chromatography (HPLC) grade (Merck, Darmstadt, Germany).

Mass spectral experiments were performed to survey for a wide array of AZAs with an analytical system consisting of an AB-SCIEX-4000 Q Trap, triple quadrupole mass spectrometer equipped with a TurboSpray interface coupled to an Agilent model $1100 \mathrm{LC}$. The LC equipment included a solvent reservoir, in-line degasser (G1379A), binary pump (G1311A), refrigerated autosampler (G1329A/G1330B), and temperature-controlled column oven (G1316A).

Separation of AZAs ( $5 \mu \mathrm{L}$ sample injection volume) was performed by reverse-phase chromatography on a C8 phase. The analytical column $(50 \times 2 \mathrm{~mm})$ was packed with $3 \mathrm{~mm}$ Hypersil BDS $120 \AA$ (Phenomenex, Aschaffenburg, Germany) and maintained at $20^{\circ} \mathrm{C}$. The flow rate was $0.2 \mathrm{~mL} \mathrm{~min}^{-1}$, and gradient elution was performed with two eluents, where eluent A was water and B was acetonitrile/water (95:5 v/v), both containing $2.0 \mathrm{mM}$ ammonium formate and $50 \mathrm{mM}$ formic acid. Initial conditions were 8 min column equilibration with $30 \% \mathrm{~B}$, followed by a linear gradient to $100 \% \mathrm{~B}$ in $8 \mathrm{~min}$ and isocratic elution until 18 min with $100 \%$ B then returning to initial conditions until $21 \mathrm{~min}$ (total run time: $29 \mathrm{~min}$ ).

AZA profiles were determined in one period (0-18) min with curtain gas: 10 psi, CAD: medium, ion spray voltage: 5500 $\mathrm{V}$, temperature: ambient, nebulizer gas: 10 psi, auxiliary gas: off, interface heater: on, declustering potential: $100 \mathrm{~V}$, entrance potential: $10 \mathrm{~V}$, exit potential: $30 \mathrm{~V}$. SRM experiments were carried out in positive ion mode by selecting the transitions shown in Table 2. 


\section{Precursor ion eXPeriments}

Precursors of the fragments $\mathrm{m} / \mathrm{z} 348, \mathrm{~m} / \mathrm{z}, 360$ and $\mathrm{m} / \mathrm{z}, 362$ were scanned in the positive ion mode from $\mathrm{m} / \mathrm{z} 400$ to 950 under the following conditions: curtain gas: 10 psi, CAD: medium, ion spray voltage: $5500 \mathrm{~V}$, temperature: ambient, nebulizer gas: 10 psi, auxiliary gas: off, interface heater: on, declustering potential: $100 \mathrm{~V}$, entrance potential: $10 \mathrm{~V}$, collision energy: $70 \mathrm{~V}$, exit potential: $12 \mathrm{~V}$.

\section{RESULTS}

\section{Physical and Chemical parameters}

Surface temperature in the area ranged from $18-21^{\circ} \mathrm{C}$ (Table 1 ) and revealed three different sub-areas. High surface temperature $\left(20.5-21^{\circ} \mathrm{C}\right)$ was observed south (Stat. 1-3), whereas temperature north of Punta Salinas (Stat. 6 and 7) was distinctly lower $\left(18-19^{\circ} \mathrm{C}\right)$. Surface temperature in the northern part (Stat. 8-11) and in the southern area (Stat. 4 and
5) were between $19^{\circ} \mathrm{C}$ and $20^{\circ} \mathrm{C}$. Surface salinity was higher in the southern part (34.9-35.0) and slightly lower in the northern part, reaching 35.0 (Table 1). CTD vertical profiles analyzed for a southern coastal transect from Chancay to La Partida (St. 1, 3 and 4, Fig. 2) showed a moderate thermocline formed by 5 isotherms $\left(17-21^{\circ} \mathrm{C}\right)$ in the layer of 0 to $10 \mathrm{~m}$ depth. Salinity values showed the presence of a mixing process between Cold Coastal Waters (CCW) and waters from Chancay River up to $6 \mathrm{~m}$ depth in station 3. Under this layer of seawater, $\mathrm{CCW}$ predominated with homogeneous salinity of 34.9 and temperatures of $16-17^{\circ} \mathrm{C}$.

Dissolved oxygen in surface waters in the area ranged from 1.9 to $8.8 \mathrm{~mL} \mathrm{~L}^{-1}$ (Table 1). Low oxygen concentrations of 1.9 to $3.3 \mathrm{~mL} \mathrm{~L}^{-1}$ were observed in the middle of the area off Huacho (Station 5-7). Low transparency was observed in the north (Stat. 9, 10 and 11) and southern part (Stat. 2 and 3 ) of the study area (Table 1).

Table 1. Physical and chemical data of surface temperature, Secchi depth, salinity, oxygen, nitrate $\left(\mathrm{NO}_{3}\right)$, phosphate $\left(\mathrm{PO}_{4}\right)$, silicate $\left(\mathrm{SiO}_{4}\right)$ and chlorophyll a (Chl a). For location of stations see Fig. 1 / Datos físicos y químicos de temperatura superficial, profundidad de disco Secchi; salinidad; datos químicos: oxígeno, nitrato $\left(\mathrm{NO}_{3}\right)$, fosfato $\left(\mathrm{PO}_{4}\right)$, silicato $\left(\mathrm{SiO}_{4}\right)$ y clorofila a $(\mathrm{Chl}$ a). Para la localización de estaciones ver Fig. 1

\begin{tabular}{|c|c|c|c|c|c|c|c|c|c|c|c|}
\hline Stat & $\begin{array}{c}\text { Latitude (S) } \\
\text { Longitude (W) }\end{array}$ & $\begin{array}{l}\text { Depth } \\
{[\mathrm{m}]}\end{array}$ & $\begin{array}{l}\text { Surf. } \\
\text { temp. } \\
{\left[{ }^{\circ} \mathrm{C}\right]}\end{array}$ & $\begin{array}{l}\text { Secchi } \\
\text { depth } \\
{[\mathrm{m}]}\end{array}$ & $\begin{array}{c}\text { Sample } \\
\text { depth } \\
{[\mathrm{m}]}\end{array}$ & Sal. & $\begin{array}{l}\text { Oxygen } \\
{\left[\mathrm{mL} \mathrm{L}^{-1}\right]}\end{array}$ & $\begin{array}{c}\text { Chl } a \\
{\left[\mu \mathrm{g} \mathrm{L}^{-1}\right]}\end{array}$ & $\begin{array}{l}\mathrm{NO}_{3} \\
{[\mu \mathrm{m}]}\end{array}$ & $\begin{array}{l}\mathrm{PO}_{4} \\
{[\mu \mathrm{m}]}\end{array}$ & $\begin{array}{l}\mathrm{SiO}_{4} \\
{[\mu \mathrm{m}]}\end{array}$ \\
\hline \multirow[t]{2}{*}{1} & $11^{\circ} 38.04^{\prime} ; 77^{\circ} 15.51^{\prime}$ & 20 & 21.0 & 3.0 & 0 & 34.95 & 8.78 & 0.57 & 35.28 & 2.40 & 4.81 \\
\hline & & & & & 10 & 35.02 & 1.06 & 0.13 & 22.77 & 6.13 & 2.50 \\
\hline \multirow[t]{2}{*}{2} & $11^{\circ} 40.90^{\prime} ; 77^{\circ} 24.61^{\prime}$ & 81 & 20.8 & 1.5 & 0 & 35.01 & 7.85 & 2.02 & 5.11 & 4.05 & 2.12 \\
\hline & & & & & 10 & 35.07 & 1.30 & 0.18 & 4.50 & 4.63 & 1.54 \\
\hline \multirow[t]{2}{*}{3} & $11^{\circ} 35.99^{\prime} ; 77^{\circ} 18.97^{\prime}$ & 41 & 20.5 & 2.0 & 0 & 35.00 & 5.54 & 2.58 & 3.80 & 3.73 & 1.83 \\
\hline & & & & & 10 & 35.04 & 0.66 & 0.05 & 24.10 & 4.85 & 4.42 \\
\hline \multirow[t]{2}{*}{4} & $11^{\circ} 24.00^{\prime} ; 77^{\circ} 31.55^{\prime}$ & 44 & 19.8 & 2.5 & 0 & 35.02 & 6.76 & 1.89 & 23.40 & 2.29 & 1.06 \\
\hline & & & & & 10 & 35.03 & 1.09 & 0.05 & 33.90 & 4.58 & 5.00 \\
\hline 5 & $11^{\circ} 17.97^{\prime} ; 77^{\circ} 41.03$ & 60 & 19.5 & 3.5 & 0 & 35.02 & 3.33 & nd & nd & nd & nd \\
\hline 6 & $11^{\circ} 12.87^{\prime} ; 77^{\circ} 41.39^{\prime}$ & 52 & 18.8 & 4.5 & 0 & 35.00 & 2.94 & nd & nd & nd & nd \\
\hline \multirow[t]{2}{*}{7} & $11^{\circ} 08.14^{\prime} ; 77^{\circ} 39.27^{\prime}$ & 28 & 18.0 & 6.0 & 0 & 34.01 & 1.89 & 0.23 & 38.30 & 4.79 & 3.37 \\
\hline & & & & & 10 & 34.20 & 1.62 & 0.18 & 26.78 & 4.85 & 1.63 \\
\hline \multirow[t]{2}{*}{8} & $10^{\circ} 51.18^{\prime} ; 77^{\circ} 45.61^{\prime}$ & 35 & 19.4 & 2.5 & 0 & 35.01 & 6.53 & 1.37 & 28.81 & 3.41 & 4.23 \\
\hline & & & & & 10 & 35.05 & 0.98 & 0.46 & 26.25 & 4.90 & 4.13 \\
\hline \multirow[t]{2}{*}{9} & $10^{\circ} 48.62^{\prime} ; 77^{\circ} 47.31^{\prime}$ & 26 & 19.6 & 2.0 & 0 & 34.97 & 6.64 & 1.32 & 14.98 & 3.25 & 1.73 \\
\hline & & & & & 10 & 35.02 & 1.17 & 0.10 & 30.29 & 5.17 & 3.65 \\
\hline 10 & $10^{\circ} 44.57^{\prime} ; 77^{\circ} 50.16^{\prime}$ & 19 & 19.5 & 2.0 & 0 & 34.11 & 5.81 & nd & nd & nd & nd \\
\hline \multirow[t]{2}{*}{11} & $10^{\circ} 40.55^{\prime} ; 77^{\circ} 53.20^{\prime}$ & 19 & 19.2 & 2.0 & 0 & 34.43 & 6.32 & 1.24 & 26.56 & 2.77 & 1.35 \\
\hline & & & & & 10 & 34.90 & 2.03 & 0.70 & 29.44 & 4.37 & 4.04 \\
\hline
\end{tabular}

Surf. temp.: surface temperature, Sal.; salinity, nd: no data 


\section{A Temperature ${ }^{\circ} \mathrm{C}$}
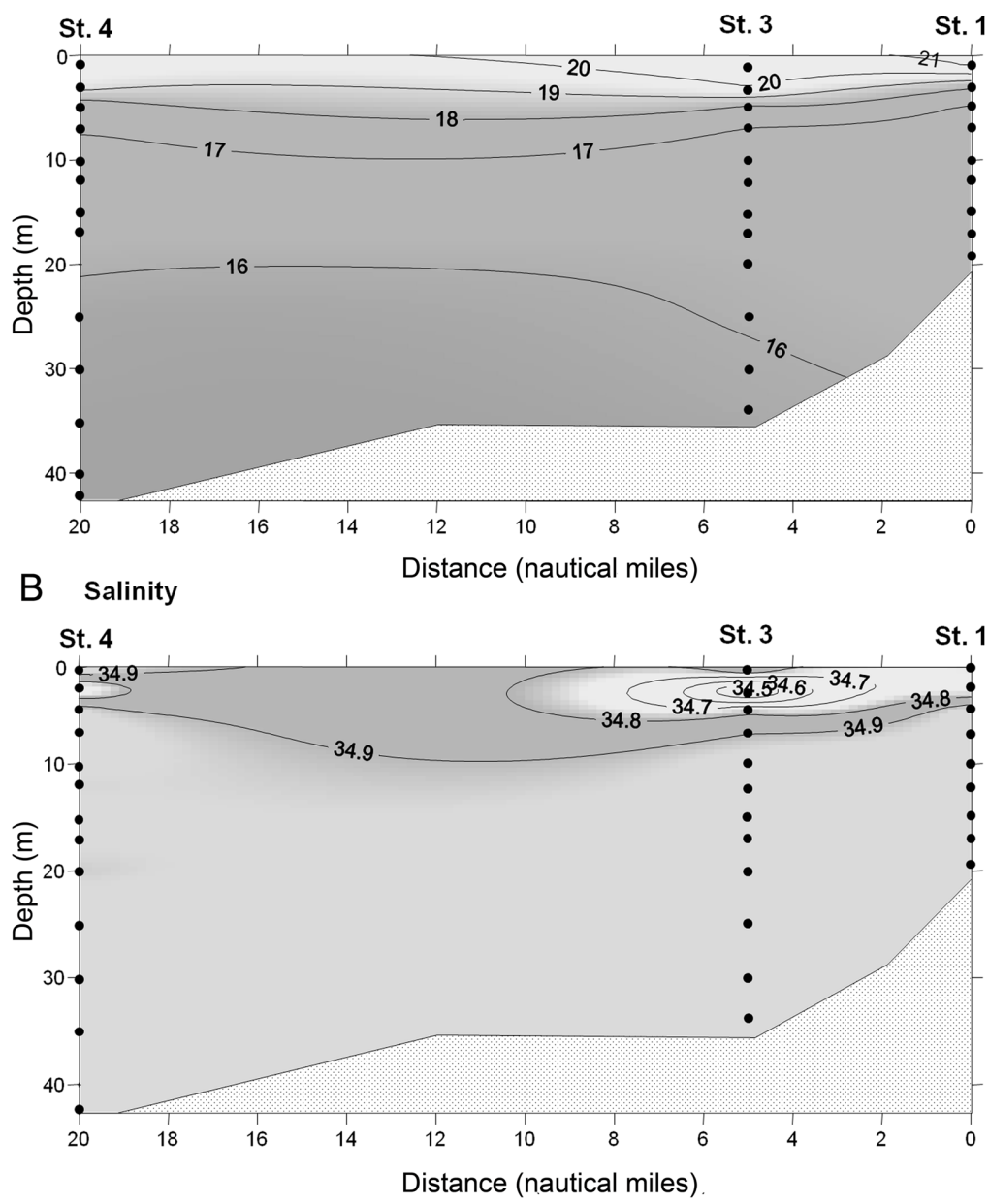

Figure 2. CTD vertical profile of temperature (A) and salinity (B) for a southern coastal transect from station 1 (Chancay) to station 4 (La Partida). See Fig. 1 for the location of sampling stations / Perfil vertical de temperatura (A) y salinidad (B) obtenido a partir de datos de CTD para el transecto costero del área sur desde estación 1 (Chancay) hasta estación 4 (La Partida). Ver Figura 1 para ubicación de estaciones de muestreo

Concentrations of nutrients are compiled in Table 1. Phosphate concentration at the surface ranged from 2.3-4.8 $\mu \mathrm{mol} \mathrm{L^{-1 }}$ and subsurface concentration at $10 \mathrm{~m}$ were slightly higher (4.4-6.1 $\left.\mu \mathrm{mol} \mathrm{L}^{-1}\right)$. Nitrate concentration varied almost tenfold, with concentrations ranging from $3.8-38.3 \mu \mathrm{mol} \mathrm{L}^{-1}$. Lowest concentrations were observed in surface waters off Chancay (Stat. 2 and 3) whereas higher nitrate concentrations prevailed off Huacho (Stat. 7, surface), Pativilca (Stat. 11), and La Partida (Stat. 4, $10 \mathrm{~m}$ depth). Silicate was generally lower in concentration, ranging from $1.1-4.8 \mu \mathrm{mol} \mathrm{L}^{-1}$ at the surface and $1.5-5.0 \mu \mathrm{mol} \mathrm{L}^{-1}$ at $10 \mathrm{~m}$ depth (Table 1).

During February $01^{\text {th }}$ and $08^{\text {th }}$, moderate wind speed (4.5$6.5 \mathrm{~m} \mathrm{~s}^{-1}$ ) was registered and produced positive anomalies $\left(+1.5-2.0 \mathrm{~m} \mathrm{~s}^{-1}\right)$. Weak winds of $2.5-3.5 \mathrm{~m} \mathrm{~s}^{-1}$ with neutral wind speed anomalies $\left(-0.5-0.5 \mathrm{~m} \mathrm{~s}^{-1}\right)$ were recorded on February $9^{\text {th }}$. These conditions of moderate wind from the beginning of February caused the coastal upwelling, which was maintained active from $9^{\circ} \mathrm{S}$ to $12^{\circ} \mathrm{S}$.

\section{Plankton communities}

Chlorophyll ranged from 0.05 to $2.58 \mu \mathrm{g} \mathrm{Chl} a \mathrm{~L}^{-1}$ (Table 1) with highest values found in the surface samples of southern stations 2 and 3 (Fig. 3A). The microplankton communities in the study area were mainly dominated by diatoms, with, Skeletonema costatum (Greville) Cleve, Leptocylindrus danicus Cleve, Leptocylindrus minimus Gran, Thalassiosira 
Table 2. Mass transitions $\mathrm{m} / \mathrm{z}$ ( $\mathbf{Q} 1>\mathbf{Q} 3$ mass) and their respective AZAs / Espectrometría de masa $\mathrm{m} / \mathrm{z}$ (Q1>Q3 masa) y AZAs correspondientes

\begin{tabular}{clc}
\hline Mass transition & \multicolumn{1}{c}{ Toxin } & $\begin{array}{c}\text { Collision energy } \\
(\mathrm{CE})[\mathrm{V}]\end{array}$ \\
\hline & & \\
$716>698$ & AZA-33 & 40 \\
$816>798$ & AZA-39 & 40 \\
$816>348$ & AZA-39 & 70 \\
$828>658$ & AZA-3 & 70 \\
$828>810$ & AZA-3 & 40 \\
$830>812$ & AZA-38 & 40 \\
$830>348$ & AZA-38 & 70 \\
$842>672$ & AZA-1 & 70 \\
$842>824$ & AZA-1, AZA-40 & 40 \\
$842>348$ & AZA-40 & 70 \\
$844>826$ & AZA-4, AZA-5 & 40 \\
$846>828$ & AZA-37 & 40 \\
$846>348$ & AZA-37 & 70 \\
$854>670$ & AZA-41 & 70 \\
$856>672$ & AZA-2 & 70 \\
$856>838$ & AZA-2 & 40 \\
$858>840$ & AZA-7, AZA-8, & 40 \\
$858>348$ & AZA-9, AZA-10, AZA-36, AZA-36 & 70 \\
$868>362$ & Undescribed & 70 \\
$870>852$ & Me-AZA-2, AZA-42 & 40 \\
$872>854$ & AZA-11, AZA-12 & 40 \\
\hline
\end{tabular}

subtilis (Ostenfeld) Gran, and Thalassionema nitzschioides (Grunow) Mereschkowsky, as the most abundant species. Among Dinophyceae, large thecate species like Protoperidinium depressum (Baily) Balech and Tripos furca were present, as well as a number of species of the genus Prorocentrum, i.e., Prorocentrum cordatum (Ostenfeld) J.D.Dodge, Prorocentrum gracile and Prorocentrum micans [for a full table of phytoplankton species and abundances see Suppl. 1]. Phytoplankton species were differently distributed in the area. Small $(<10 \mu \mathrm{m})$ unidentified flagellates had highest abundances of up to $2 \times 10^{6}$ cells $\mathrm{L}^{-1}$ in the north and off $\mathrm{La}$ Partida (Fig. 3B). Some diatom species, as exemplarily shown for Guinardia striata (Stolterfoth) Hasle, were highly abundant in the northern part only (Fig. 3C), whereas others (e.g., Skeletonema costatum; Fig. 3D) were almost completely restricted to the southern area. Among Dinopyhceae, a notably dense bloom of $P$. cordatum (Fig. 3E) was recorded. It had a peak density of $>11 \times 10^{6}$ cells $\mathrm{L}^{-1}$ that occurred at station 1 , with cells densities at the neighbouring stations 2 and 3 being more than one order of magnitude lower.
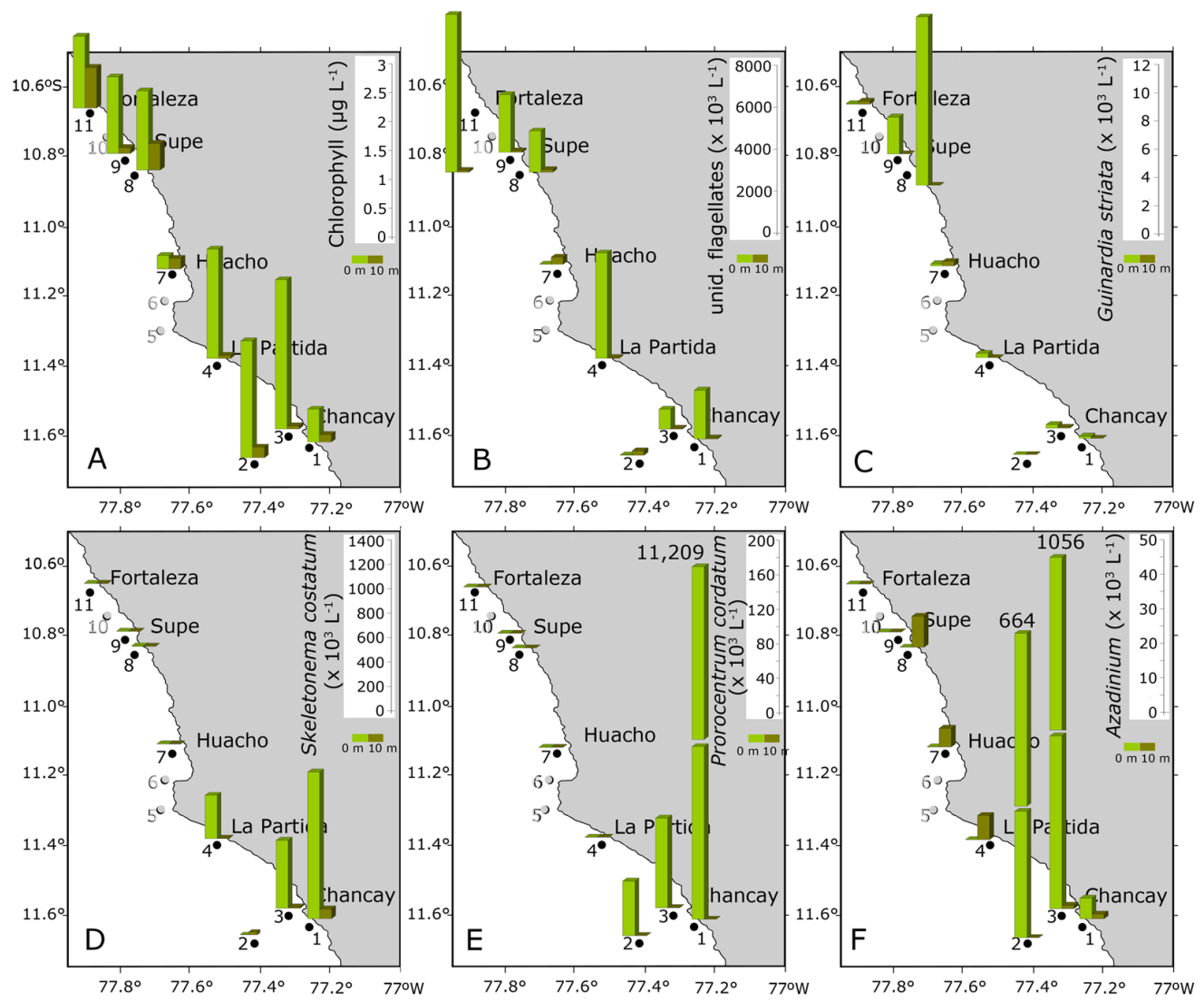

Figure 3. Distribution and abundance of (A) chlorophyll a, (B) unidentified flagellates, (C) Guinardia striata, (D) Skeletonema costatum, (E) Prorocentrum cordatum, and (F) Azadinium spp. / Distribución y abundancia de (A) clorofila a, (B) flagelados no-identificados, (C) Guinardia striata, (D) Skeletonema costatum, (E) Prorocentrum cordatum, y (F) Azadinium spp. 


\section{The Azadinium Bloom}

At two stations off Chancay (stations 2 and 3), a dense bloom of a small thecate dinophycean species identified as Azadinium was observed (Fig. 3F). This bloom was accompanied by a reddish-brown discoloration of the water. Using light microscopy the causative species (Fig. 4A, B) was provisionally identified and reported as 'Azadinium cf. spinosum' based on general size and shape and on the presence of a short antapical spine. Cell size of formalin fixes cells in light microscopy (LM) was estimated to range from 12.0 to $16.2 \mu \mathrm{m}$ in length (mean 14.6 $\pm 1.5 \mathrm{SD} ; \mathrm{n}=15$ ) and from 7.2 to $10.2 \mu \mathrm{m}$ in width (mean 8.7 $\pm 1.4 \mathrm{SD} ; \mathrm{n}=15)$.

Because species of the genus Azadinium are known as producers of azaspiracids, samples taken at station 2 ( 0 and $10 \mathrm{~m}$ depth) were analysed for the presence of these toxins by LC-MS/MS. However, no known AZAs (Table 2) were detected in the samples. Considering the density of Azadinium at station $2\left(6.64 \times 10^{5}\right.$ cells $\left.\mathrm{L}^{-1}\right)$, the limit of detection (LOD) for these measurements was determined as $0.02 \mathrm{fg} \mathrm{cell}^{-1}$. In order to test for yet unknown AZA variants, precursor ion scans of the characteristic AZA fragments $m / z, 348,360$ and 362 were performed, but resulted negative. The LOD of precursor ion fragments is significantly higher as of the more sensitive SRM experiments and was determined as $1 \mathrm{fg} \mathrm{cell}^{-1}$. In summary, the Azadinium bloom species reported here can be regarded as a non AZA-producer.

Species of Azadinium are small and rather difficult to be identified at species level by LM, so a detailed study using electron microscopy was performed.

\section{ELECTRON MiCROSCOPY}

In the subsample of station 2 analysed with SEM, a large number of cells (> 100) of Azadinium were inspected. All specimens that had distinctive features in view presented the same morphotype, which we determined here as Azadinium polongum Tillmann. The cells were ovoid and slightly dorsoventrally compressed (Fig. 4C-F). Cells varied in size, ranging from 13.5 to $20.7 \mu \mathrm{m}$ in length (mean: $16.9 \pm 1.6 \mu \mathrm{m}, \mathrm{n}$ =69) and 10.0 to $15.3 \mu \mathrm{m}$ in epithecal width (mean: $12.8 \pm$ $1.3 \mu \mathrm{m} ; \mathrm{n}=49)$, with a length/width ratio of $1.3 \pm 0.1 \mu \mathrm{m}(1.1-$ $1.5, \mathrm{n}=48$ ). A single antapical spine almost symmetrically formed the termination of a hemispherical to conical shaped hypotheca (Figs. 4C-F; 6E-G). Occasionally, the spine arose from a small bump (Fig. 6G). The length of the spine was $1.2 \pm$ $0.2 \mu \mathrm{m}(0.7-1.6, \mathrm{n}=63)$. A ventral pore was located at the border of Plate 1' and 1", at the lower third level of the epitheca, embedded in a cavity of Plate 1" (Figs. 4C, D; 5A). This pore has a distinct outer rim measuring $0.34 \pm 0.01 \mu \mathrm{m}(\mathrm{n}=8)$ in diameter.
The first apical plate $1^{\prime}$ had an ortho pattern and was progressively narrowed in its anterior part and ended in a slender tip abutting the pore plate (Fig. 5A, G). Both lateral apical plates 2 ' and 4' clearly invaded the ventral area, with their tapering posterior ends pointing toward the sulcus (Figs. 4C, D; 5A). The dorsal apical plate $3^{\prime}$ was elongated in its posterior part where it abutted the small intercalary plate $2 \mathrm{a}$ (Figs. 4E, F; 5E, F). Three anterior intercalary plates were arranged more or less symmetrically on the dorsal side of the epitheca. The small second intercalary plate (2a) occurred in two different arrangements, either tetragonal almost symmetrically located above plate 3" (Figs. 4E, 5E), or in a penta-configuration (i.e., plate 2 a was pentagonal) with plate 2 a in contact to 3 " and 4 " (Figs. 4F, 5F). For a total number of 59 cells where plate $2 \mathrm{a}$ was visible, 31 cells $(51 \%)$ had a tetragonal, and 28 cells (47\%) had a pentagonal configuration, respectively. The first ( $\left.1^{\prime \prime}\right)$ and last (6") precingular plates both contacted only four epithecal plates (i.e., plate 1" was not in contact to plate 1a) (Fig. 5BE). This was the case for all 63 cells where this epithecal area was visible.

The episome ended with a conspicuous apical pore complex (APC) (Fig. 5G-J). The apical pore was covered by a cover plate and was located in the dorsal part of an elongated pore plate, the latter having a roundish dorsal part that was considerable prolonged ventrally. A conspicuous rim bordered the dorsal and lateral margins of the pore plate with the lateral rim running almost parallel in its distal end. Ventrally the pore plate abutted the first apical plate and the X-plate, which was slender and elongated (Fig. 5H, J). The X-plate had a very characteristic three-dimensional structure, with finger-like protrusions contacting the cover plate (Fig. 5H, I). The elongated pore plate was $2.34 \pm 0.11 \mu \mathrm{m}$ in length $(n=5)$ and $1.68 \pm 0.13 \mu \mathrm{m}$ in width $(\mathrm{n}=14)$.

The cingulum was wide [3.4 $\pm 0.3 \mu \mathrm{m}(2.7-4.4, \mathrm{n}=65)]$, descending, displaced by about half of its width, and was composed of six comparably sized plates (Fig. 6A, C). The deeply concave sulcus (Figs. 4C, D; 6B-D) was composed of 5 sulcal plates with two smaller and centrally located sulcal plates forming a concave central pocket (Fig. 6B-D). The hypotheca consisted of 6 postcingular plates and 2 antapical plates (Fig. $6 \mathrm{~A})$.

For most of the plates, the pattern and arrangement of $A z$. polongum in the bloom field sample was rather stable. Nevertheless, the shape of single plates was somewhat variable as exemplarily compiled in Figure 7 for the central intercalary plate $2 \mathrm{a}$. This plate was rectangular in quadra arrangement or mainly triangular in its posterior part when in pentagonal arrangement. However, rarely the posterior part of a pentagonal 2a plate was rounded (Fig. $7 \mathrm{~J}$ ), or the anterior part of a 

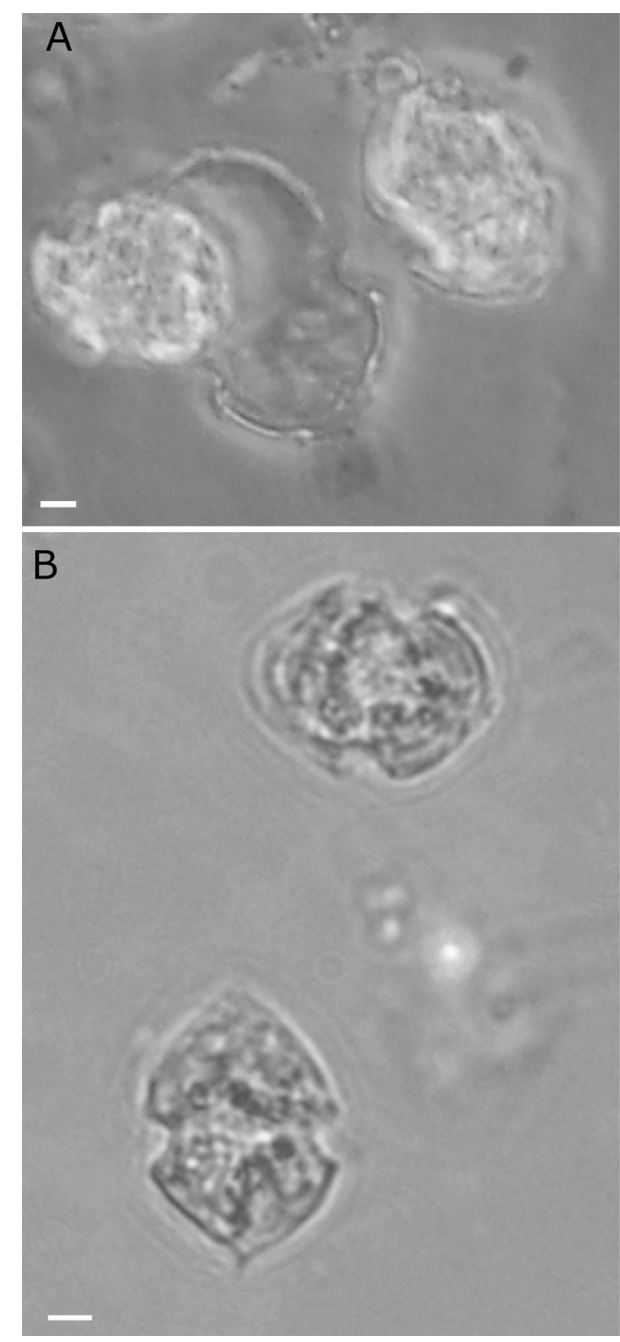
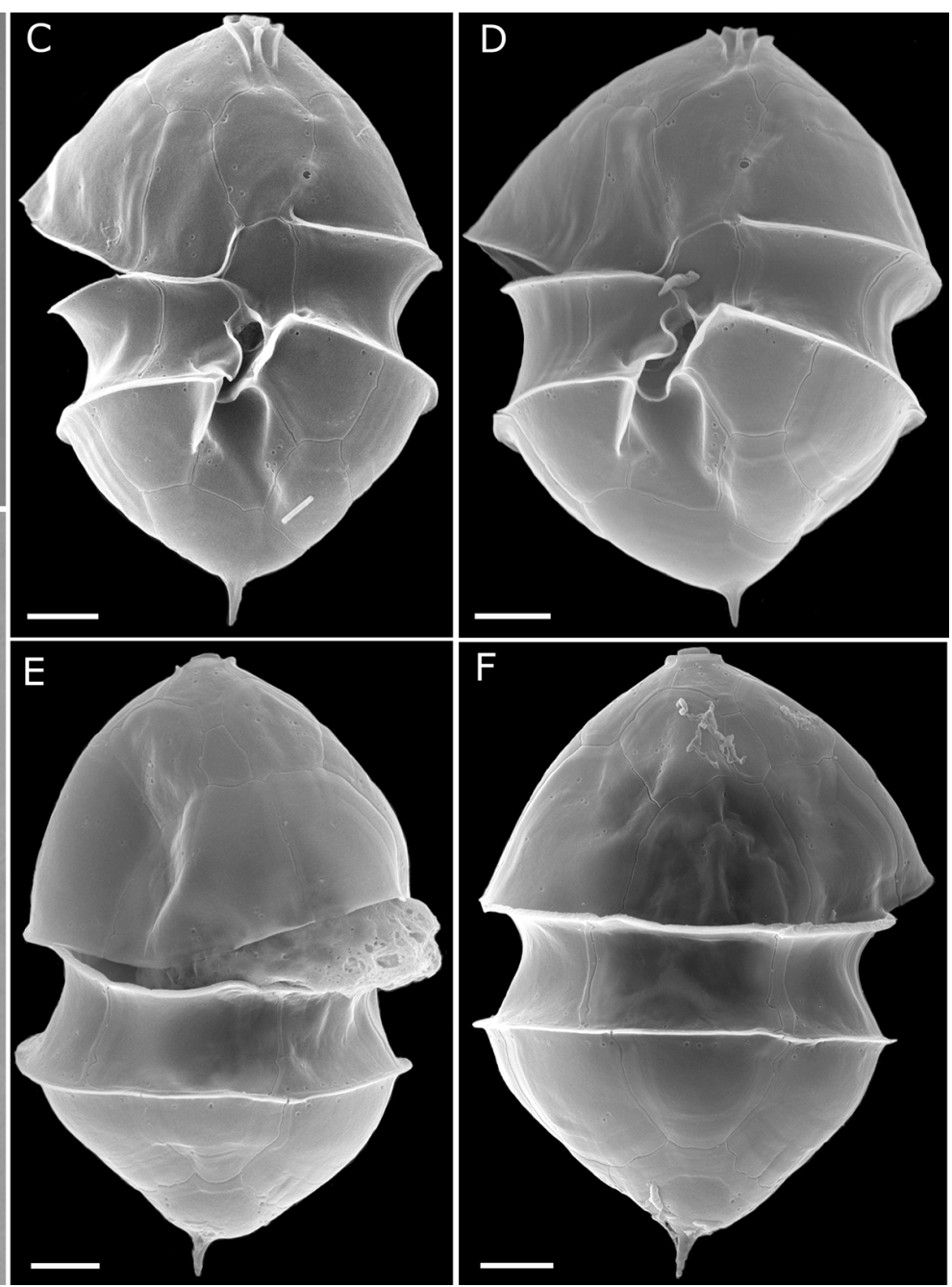

Figure 4. Azadinium polongum from Station 2. LM (A, B), and SEM (D-F) micrographs, in ventral (C, D) or dorsal (E, F) view. Scale bars $=2 \mu \mathrm{m} /$ Azadinium polongum de la estación 2. Microfotografías de microscopio de luz (A, B), y microscopio electrónico de barrido (D-F), en vista ventral (C, D) o vista dorsal (E, F). Barras de escala $=2 \mu \mathrm{m}$

tetragonal plate was triangularly pointed (Fig. 7E). Exceptionally plate 2 a was displaced and not in touch to plate $3^{\prime}$ anymore (Fig. 7F). Rounded convexities in the sutures of plate $2 \mathrm{a}$ were mostly present but quite differently expressed on both or just one of the lateral sides (Fig. 7).

\section{Discussion}

The oceanographic conditions off the Peruvian coast during 2014 were heavily influenced by atmospheric fluctuations and the arrival of different Kelvin waves, impacting in the coastal upwelling system. These conditions started during austral spring of 2013, with Kelvin waves recorded in January, March, April and May/June in 2014. The coastal area was affected by a reduction in the nutrients availability in the surface layer, and death and migrations of a number of different marine organisms mainly in the northern and central zones of the Peruvian coast was observed (IMARPE 2014, Graco et al. 2016).

During February 2014, when the bloom of Azadinium off Chancay occurred, upwelled waters between $10.6^{\circ} \mathrm{S}$ and $11.4^{\circ} \mathrm{S}$ were identified. These waters were distributed from Fortaleza to La Partida, while high surface temperatures (20.5-2 ${ }^{\circ} \mathrm{C}$ ) were registered to the south of Charimar and Chancay, as a result of warming that was observed in the Peruvian coast (IMARPE 2014). Nitrate and phosphate 

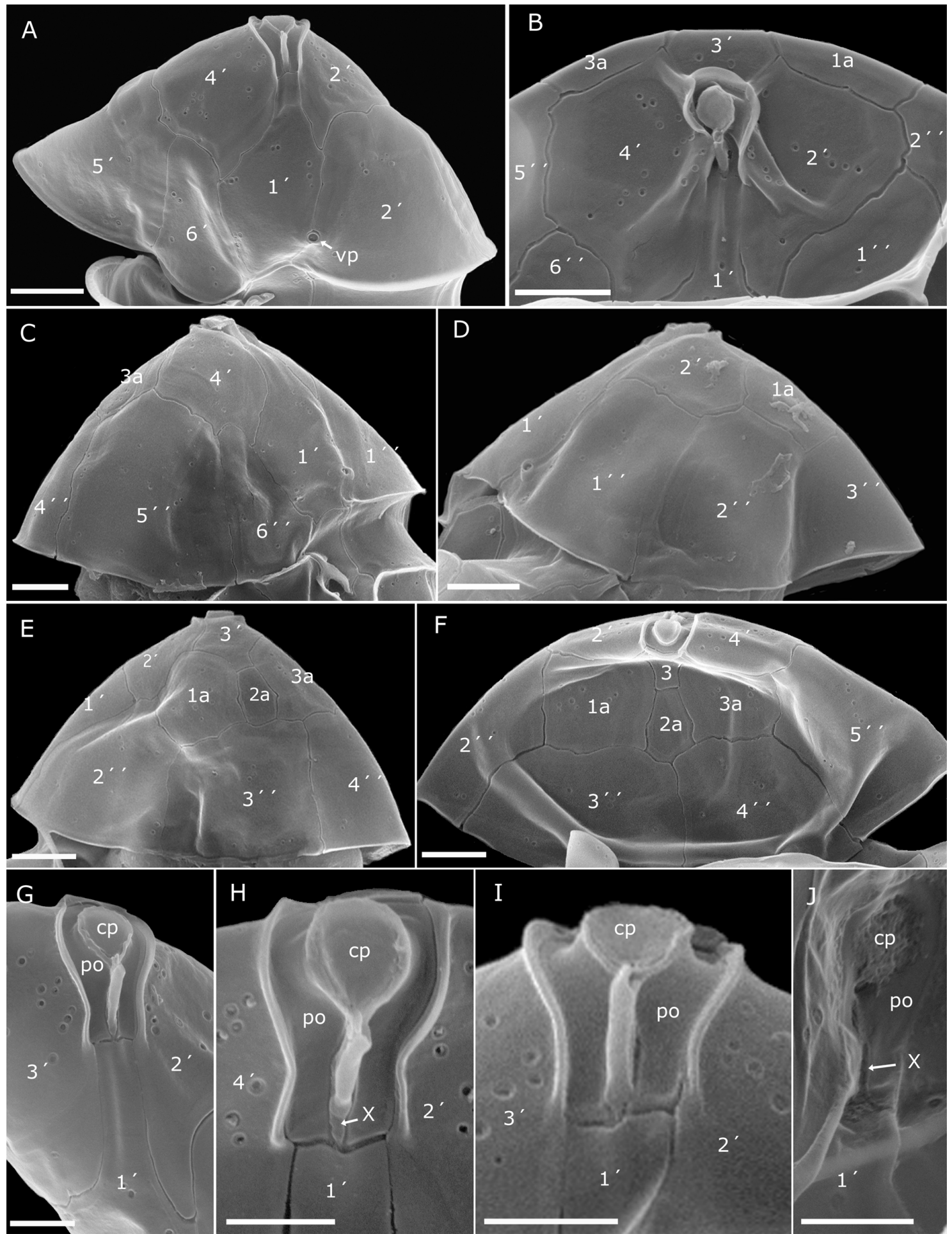

Figure 5. Azadinium polongum. SEM micrographs of different cells. (A-F) Epitheca in ventral (A), apical (B), right lateral (C), left lateral (D), and dorsal (E, F) view. Note that plate 2a is four-sided (quadra configuration) in (E) and five-sided (penta configuration) in (F). (G-J) Detailed view of the apical pore complex in external (G-I) and internal ( $)$ view. $P o=$ apical pore plate; $X=X$-plate; $c p=$ cover plate. Scale bars $=\mathbf{2} \mu \mathrm{m} /$ Azadinium polongum, microfotografías de microscopio electrónico de barrido de distintas células. (A-F) Epiteca en vista ventral (A), apical (B), lateral derecho (C), lateral izquierdo (D), y vista dorsal (E, F). Nótese que la placa 2a es de configuración cuadra en (E) y penta en (F). (G-J) Vista detallada del complejo del poro apical en vista externa (G-I) e interna (J). Po = placa del poro apical; $X=$ placa $X ; c p=$ placa de cubierta. Barras de escala $=2 \mu \mathrm{m}$

600 Tillmann et al.

Azadinium polongum in Peru 

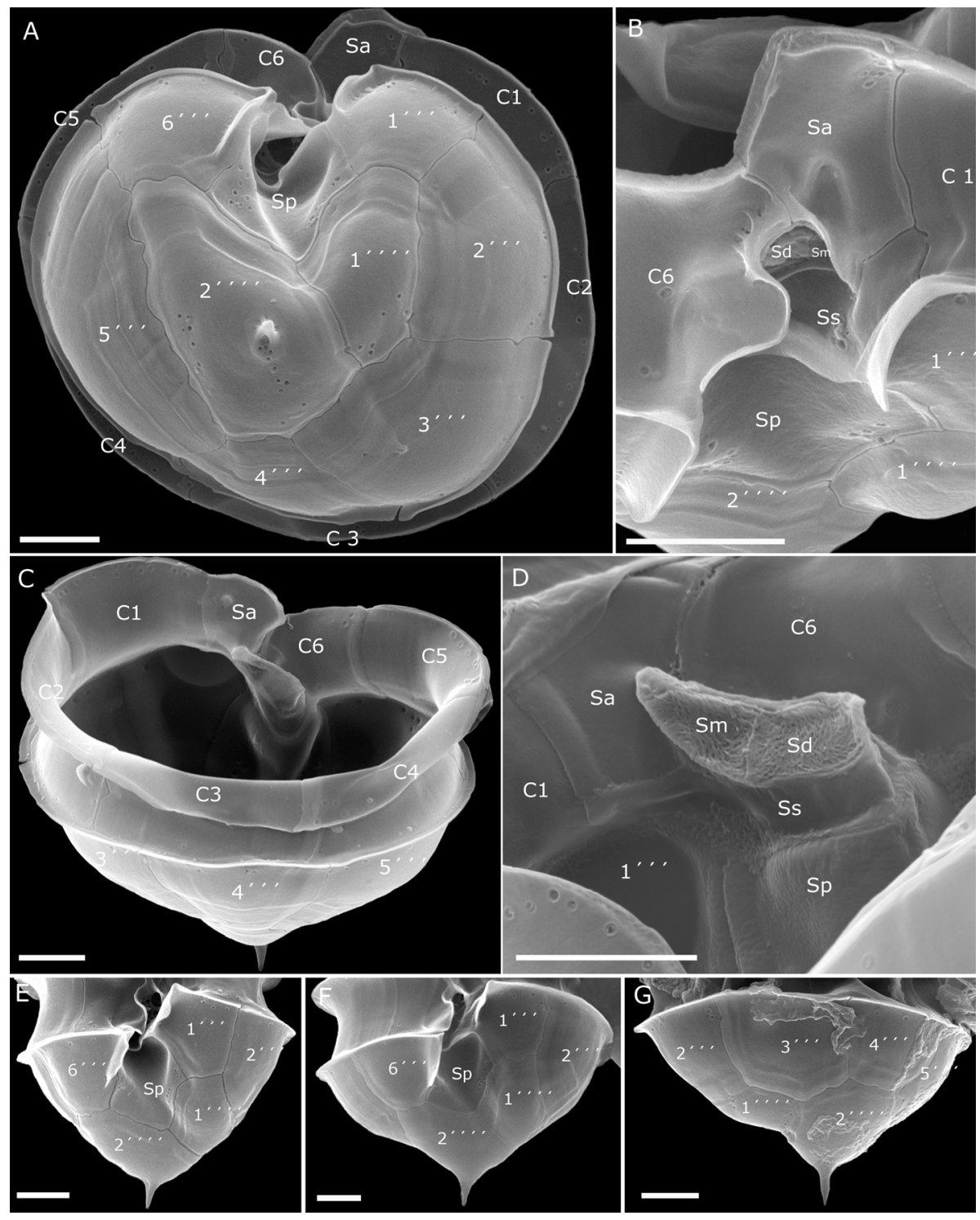

Figure 6. Azadinium polongum. SEM micrographs of different cells. (A) Antapical view of hypothecal plates. (B-C) Details of the sulcal plate arrangement in ventral (B) and internal (C) view. (D) Dorsal view of the hypotheca showing the series of cingular plates. $C=$ Series of cingular plates; $S a=a n t e r i o r$ sulcal plate; $\mathrm{Sp}=$ = posterior sulcal plate; $\mathrm{Ss}=$ =left sulcal plate; $\mathrm{Sm}=$ =median sulcal plate; $\mathrm{Sd}=$ right sulcal plate). (E-G) Variability in shape of the antapex of the cell. Scale bars $=\mathbf{2} \boldsymbol{\mu m}$ / Azadinium polongum. Microfotografías de células distintas en microscopio electrónico de barrido. (A) Vista antapical de placas hipotecales. (B-C) Detalles de la disposición de las placas sulcales en vista ventral (B) e interna (C). (D) Vista dorsal de la hipoteca mostrando la serie de placas cingulares. $\mathrm{C}=$ Serie de placas cingulares; $\mathrm{Sa}=$ placa sulcal anterior; $\mathrm{Sp}=$ placa sulcal posterior; $\mathrm{Ss}=$ placa sulcal izquierda; $\mathrm{Sm}$ = placa sulcal media; $\mathrm{Sd}=$ placa sulcal derecha). $(\mathrm{E}-\mathrm{G})$ Variabilidad de forma del antápex de la célula. Barras de escala $=2 \mu \mathrm{m}$

concentration at that time were in normal high ranges for the season (austral summer). Low silicate concentration in the upper layer agreed with low values usually registered in austral summer $(1.0 \mu \mathrm{m})$, which were caused by diatom blooms that deplete this nutrient (Zuta \& Guillén 1970, Graco et al. 2007). In the southern area off Chancay, nitrate concentrations were significantly lower compared to other stations and correspond with the location of the Azadinium bloom. This bloom attracted attention because of the suspicious reddish-brown water discoloration and high abundances and dominance of a small thecate dinoflagellate. Based on the general cell size, shape, and the identification of a single antapical spine, the first LM observations led to the provisionally designation of the bloom species as $A z$. cf. spinosum. Since Az. spinosum 


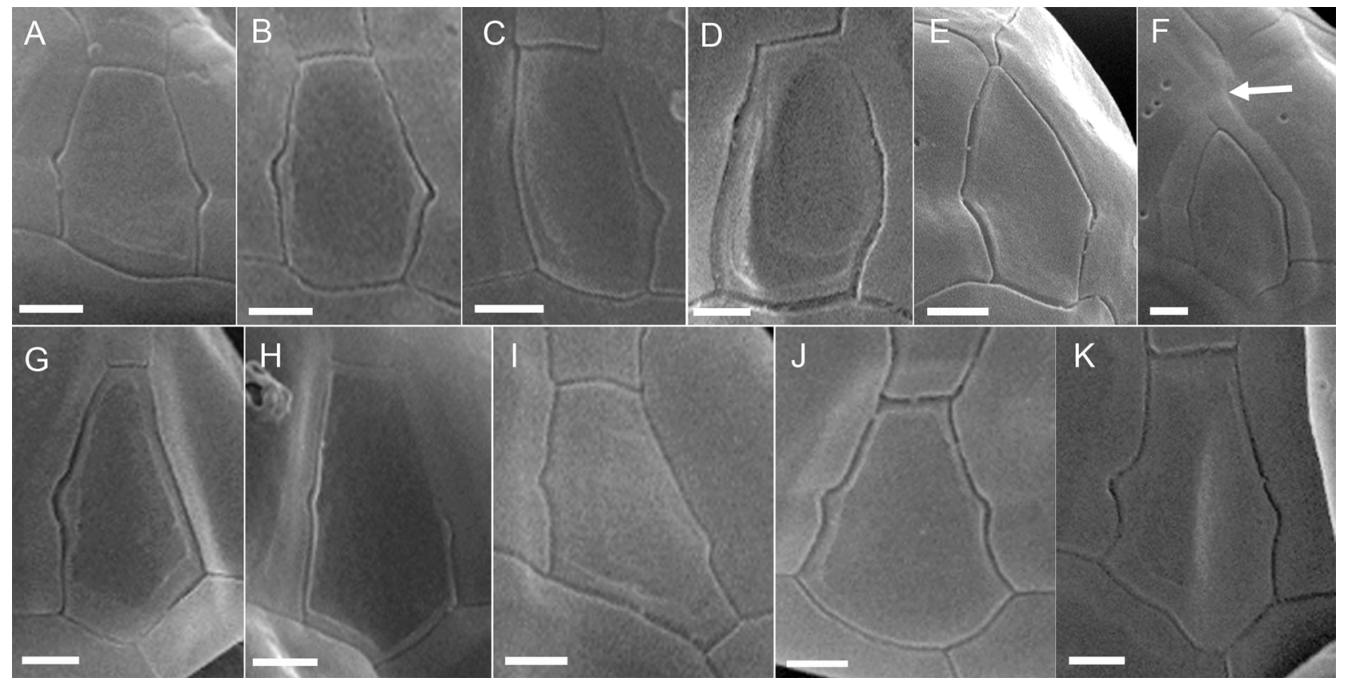

Figure 7. Azadinium polongum. SEM micrographs of different cells. (A-K) Variability in shape of the dorsal apical plate 2a. (A-F) Plate 2a foursided in quadra configuration. (G-K) Plate 2a five-sided in penta configuration. Note that in (F) plate 2a is displaced and without contact to plate 3' (white arrow). Scale bars $\mathbf{0} \mathbf{0 . 5} \boldsymbol{\mu \mathrm { m }}$ / Azadinium polongum. Microfotografías de células distintas en microscopio electrónico de barrido. (A-K) Variabilidad de la placa apical dorsal 2a. (A-F) Placa 2a en configuración cuadra. (G-K) Placa 2a en configuración penta. Nótese que en (F) la placa 2a está desplazada y carece de contacto con la placa 3' (flecha blanca). Barras de escala $=0,5 \mu \mathrm{m}$

is a source species of AZAs (Tillmann et al. 2009) and thus is on the IOC-UNESCO taxonomic reference list of harmful micro alga (<http://www.marinespecies.org/hab/ aphia.php? $\mathrm{p}=$ taxdetails \&id=391509>), it encouraged us to more specifically look for the presence of AZAs and to more precisely identify the causative species.

Species of Amphidomataceae are very similar in general size and shape and are furthermore rather similar to a number of small species of Heterocapsa, so reliable identification of fixed cells of Azadinium from field samples is problematic. However, there is a need to unambiguously identify and quantify the species to distinguish toxigenic species from their non-toxigenic relatives. This task is challenging because AZA-producing and non-toxigenic species are known to co-exist in the same water mass (Tillmann et al. 2010, 2012a). The determination of diagnostic morphological characteristics in Azadinium, such as details of the plate number and arrangement, or the location of a ventral pore, ultimately requires electron microscopy.

Our SEM investigation revealed that the Peruvian bloom corresponded to Azadinium polongum, a non-toxigenic species. This is the first record of the genus Azadinium in Peru, and the first record of $A z$. polongum in the Pacific Ocean. Up to now the species had been only documented when described in 2012 from its type locality, the Shetland Islands, in the North Atlantic (Tillmann et al. 2012a).
Moreover, our study is the first record of a high abundance bloom of Azadinium in the Pacific Ocean.

But first it is important to discuss why we classified the bloom species as Az. polongum. Morphological features important for Azadinium species designation include the number of apical and intercalary plates, the presence of an antapical spine, and most importantly, the position of the ventral pore (Tillmann \& Akselman 2016). This pore found in Azadinium is a hole distinctly larger than regular thecal pores and is surrounded by a platelet-like structure. This pore has a species specific position on the ventral part of the epitheca and is thus reported as the ventral pore (vp) (for a compilation of morphological details of all species of Azadinium see Tillmann \& Akselman 2016). Whereas many Azadinium species have the vp located close or inside of the apical pore plate, there are three species where the vp is located much more posteriorly at the suture of plate $1^{\prime}$ with $1^{\prime \prime}$, as it is found in the Peruvian bloom specimens. These are Azadinium obesum Tillmann \& Elbrächter, $A z$. spinosum, and $A z$. polongum. Az. obesum is clearly different as it lacks an antapical spine, which is found for both $A z$. spinsoum und $A z$. polongum. For the type of Az. polongum the position of the vp was described as more posteriorly positioned compared to Az. spinosum, being located in the lower third epitheca between plate 1' and 1" (Tillmann et al. 2012a). Moreover, in Az. polongum the ventral pore is clearly located on the suture and is embedded in a cavity of plate 1 ", whereas in 
Az. spinosum it is located within the 1'plate and is connected to the suture of 1' and 1" by a narrow slit (Tillmann et al. 2009). It has been emphasized that the most distinctive feature of $A z$. polongum is the shape of the pore plate, which allows a separation of $A z$. polongum (elongated pore plate) from other Azadinium species (round to ellipsoid pore plate). Related to this, the shape of the X-plate is elongated in $A z$. polongum, but round to ellipsoidal in other Azadinium species. All specimens observed in the field sample thus conformed to the description and diagnosis of Az. polongum with respect to the presence of an antapical spine, the position of the ventral pore, and the elongated shape of both the pore plate and the X-plate, which justify our designation of the Peru blooms species as Az. polongum.

It should be noted that a number of morphological details deviate from the type material and thus will be discussed in more detail. In terms of cell shape and size the Pacific population of $A z$. polongum was very similar to the type culture ShetB2. Size estimates of the Peruvian bloom species using LM (12.0-16.2 $\mu \mathrm{m}$ cell length, and 7.2-10.2 cell width) were slightly smaller than size measurements using SEM (13.5$20.7 \mu \mathrm{m}$ cell length; $10.0-15.3 \mu \mathrm{m}$ in epithecal width). Increased width of cells in SEM might occur when thecae partly collapse leading to more flat cells compared to undeformed cells which are only little if at all dorsoventrally compressed. A slightly different range of cell length probably is due to the higher number of cells measured under SEM. In any case, median cell length of Az. polongum estimated here with SEM $(16.9 \mu \mathrm{m})$ was slightly larger that median cell length of the type culture ShetB2 $(13.0 \mu \mathrm{m})$, indicating small morphometric differences between both populations.

There was a main difference between the Az. polongum type culture ShetB2 and the Pacific population concerning the plate arrangement. The first intercalary plate (1a) of the Pacific specimens was without exception not in contact with the first precingular plate ( $\left(1^{\prime \prime}\right)$. Arrangement of these two plates has been discussed as a species-specific feature, and plates 1a and 1 " being separated by the second apical plate has been observed for Azadinium cuneatum Tillmann \& Nézan, Az. obesum, and $A z$. concinnum Tillmann \& Nézan only. Our result now indicate that this feature can be variable within a species, but molecular data on the Pacific population are needed to generally evaluate the level of evolutionary identity or divergence of such geographically separated populations.

For the type culture ShetB2 of Az. polongum the second intercalary plate (2a) was always tetragonal and in contact with four plates (quadra configuration), including only one precingular plate (the dorsal plate 3 ). For the field population of Peru, however, we found the arrangement of plate $2 \mathrm{a}$ to be variable; in about half of the specimens it was pentagonal and contacting plates 3" and 4". An intraspecific variability of plate $2 \mathrm{a}$ arrangement is known for other Azadinium species. For the type culture 3D6 of Az. cuneatum, a quadra-configuration of the intercalary plate $2 \mathrm{a}$ was most abundant, but a pentaconfiguration was present in a significant percentage of cells (up to 40\%) as well (Tillmann et al. 2014b). Within a field population of Azadinium luciferelloides Tillmann \& Akselman, also both arrangements of plate $2 \mathrm{a}$ were observed, but here a pentagonal plate 2 a was a very rare exception (Tillmann \& Akselman 2016). Variability and deviation in plate patterns and arrangements are often discussed as culture artifacts. Our data provide evidence that intraspecific variability in plate arrangements can be common and abundant in a field population. The presence of both quadra-and pentaconfiguration of plate $2 \mathrm{a}$ within a single species has also been described for field populations of Peridiniella danica (Paulsen) Y.B.Okolodkov \& J.D.Dodge (Okolodkov \& Dodge 1995), although here, conspecificity of the different types is not confirmed.

Variability within the Az. polongum field population pertained not only to plate arrangement but also to the shape of plate $2 \mathrm{a}$ (Fig. 7), which has also been previously reported for the bloom population of Az. luciferelloides (Tillmann \& Akselman 2016). The second intercalary plate of the type culture of Az. polongum has been described as being particularly small and located at the posterior tip of a small and elongated plate $3^{\prime}$. However, with the high variability of plate 2 a shape, this feature was not obvious within the Pacific field population.

In addition to some morphological differences, the Pacific population of $A z$. polongum is likely to have quite different ecological requirements. The type culture of $A z$. polongum was isolated from the Shetland Islands (North Atlantic) at a water temperature of $10^{\circ} \mathrm{C}$, and in culture grows well at $10^{\circ} \mathrm{C}$ but rapidly declined at $20^{\circ} \mathrm{C}$ (Tillmann et al. 2012a). As the Pacific bloom of $A z$. polongum occurred in summer at sea surface temperatures of $c a$., $20^{\circ} \mathrm{C}$, this is an indication that the Atlantic and Pacific populations may have different temperature requirements.

Our report of high densities of up to one million cells of $A z$. polongum per liter is a first bloom record for a species of Azadinium in the Pacific Ocean. Generally, quantitative abundance data of Amphidomataceae species are hardly available. Even for Ireland, the country most seriously hit by elevated AZA concentrations in shellfish with concomitant losses for the shellfish industry (Salas et al. 2011), very little quantitative data are available almost ten years after the identification of the 
toxin source organism. The only quantitative data published so far regarding Ireland are from a time series from Killary Harbour (Tillmann et al. 2014a). They indicate that even during high AZA toxin concentrations (i.e., above the regulatory limit of $1.6 \mu \mathrm{g}$ per $\mathrm{g}$ of shellfish meat), abundance of 'Azadinium-like' cells in the water reached values lower than 25,000 cells $\mathrm{L}^{-1}$. Conspicuous blooms of $A z$. spinosum in Ireland are unlikely to go unnoticed considering the intense Irish phytoplankton monitoring program. It seems obvious that relatively low cell densities of toxigenic Azadinium are sufficient to cause high AZA accumulations in shellfish. Reports of Azadinium from other areas generally indicate rather low cell abundances (Tillmann et al. 2014b). At three stations off Chile (South Pacific Ocean), the presence of the toxigenic Az. poporum was detected with densities below 7,000 cells $\mathrm{L}^{-1}$ (Tillmann et al. 2017). A 3-year time series based on qPCR of Az. poporum from Shiwa Bay (South Korea), showed the regular presence of the species, always with low densities and peak concentrations of about 5,000 cells L ${ }^{-1}$ (Potvin et al. 2013).

The only other available records of dense Azadinium blooms come from the 1990s from the South Atlantic Ocean, where densities up to 9 × $10^{6}$ cells $\mathrm{L}^{-1}$ were reported (Akselman \& Negri 2012, Akselman et al. 2014). These blooms from 1990, 1991 and 1998, however, were different from the Peruvian bloom in several aspects. First, the Argentinean blooms were observed quite offshore at the shelf margin (ca., 100-250 m water depth), whereas the Peruvian bloom occurred in more shallow waters close to the coast. Second, few available data on vertical distribution of Azadinium during the South Atlantic blooms indicate highest abundance of Azadinium in deeper waters (25 m depth), whereas cells of the Peruvian blooms were concentrated at the surface, with very low concentrations found at $10 \mathrm{~m}$ depth. Third, all three blooms in Argentina occurred in spring at water temperatures of about $6-10{ }^{\circ} \mathrm{C}$ (Akselman et al. 2014), that is quite different to the summer bloom off Chancay occurring at a water temperature slightly above $20{ }^{\circ} \mathrm{C}$. Finally, the species causing the blooms are different. At least one of the blooms in Argentina was dominated by a new species, Az. luciferelloides, which was accompanied by lower densities of many other Amphidomatacean species, but not Az. polongum (Tillmann \& Akselman 2016). In contrast, the bloom of Peru was only composed of Az. polongum.

No AZAs were detected in the Peruvian bloom sample. Thus, given the high cell density and the sensitivity of the LCMS/MS method, the Peruvian Az. polongum can be regarded as a non-AZA producer. This is in line with the negative AZA result for the type culture of Az. polongum (Tillmann et al. 2012a) and confirms the notion that only 4 species of Amphidomataceae produce these toxins (Az. spinosum, $A z$. poporum, Az. dexteropoum, Amphidoma languida). Nevertheless, cultures of South Pacific Azadinium are needed in order to clarify the AZA production potential of local species and finally evaluate the risk potential of AZA shellfish contamination.

Although chemical analysis indicate that azaspiracids were not present in the bloom and thus the local Az. polongum must be considered as non-toxigenic, the present Azadinium bloom is an alert for coastal monitoring. There is a potential risk that other AZA producing species might be present along the Peruvian coast, as a high diversity of the genus, including AZAproducing and non-producing species, has been reported for other areas before (Tillmann et al. 2010, Tillmann \& Akselman 2016, Kim et al. 2017). Regular monitoring programs performed along the Peruvian coast since the bloom event in 2014 have not revealed the presence of Azadinium again, but occurrence, development, and bloom formation of plankton, and especially of particular plankton species, can be sporadic, intermittent and generally difficult to predict, especially in light of the continuously ongoing environmental and climate change.

\section{ACKNOWLEDGEMENT}

Thanks to the personnel of the IMARPE Phytoplankton laboratory for the support in the analysis of the samples, to Eng. Francisco Ganoza, Coordinator of the Laboratory of Huacho / IMARPE for the logistical facilities, and to IMARPE Physical Oceanography Area for giving CTD data, surface physical parameters and satellite wind data. Thanks to Wolfgang Drebing for technical support in AZA analysis. Financial support was provided by the PACES research program of the Alfred Wegener Institute as part of the Helmholtz Foundation initiative in Earth and Environment.

\section{LITERATURE CITED}

Akselman R \& RM Negri. 2012. Blooms of Azadinium cf. spinosum Elbrächter et Tillmann (Dinophyceae) in northern shelf waters of Argentina, Southwestern Atlantic. Harmful Algae 19: 30-38.

Akselman R, RM Negri \& E Cozzolino. 2014. Azadinium (Amphidomataceae, Dinophyceae) in the Southwest Atlantic: In situ and satellite observations. Revista de Biología Marina y Oceanografía 49: 511-526.

Álvarez G, E Uribe, P Ávalos, C Mariño \& J Blanco. 2010. First identification of azaspiracid and spirolides in Mesodesma donacium and Mulinia edulis from Northern Chile. Toxicon 55: 638-641.

Anderson DM, TJ Alpermann, AD Cembella, Y Collos, E Masseret \& M Montresor. 2012. The globally distributed genus Alexandrium: Multifaceted roles in marine ecosystems and impacts on human health. Harmful Algae 14: 10-35. 
Antinori JA, LM Sánchez-Ycochea, JA Mendoza, O Flores \& D Ascón. 2003. Monitoring of harmful microalgae and phycotoxins in Peru: first report of PSP toxins in shellfish. In: Villalba A, B Reguera, JL Romalde \& R Beiras (eds). Proceedings of the 4th International Conference on Molluscan Shellfish Safety, pp. 203-210. Consellería de Pesca e Asuntos Marítimos da Xunta da Galicia and IOC-UNESCO, Santiago de Compostela.

Bárcena-Martínez V, J López-Hidalgo, J Rojas-Fox, M Baylón-Coritoma, LM Sánchez-Ycochea \& O FloresSalmón. 2013. Alexandrium tamiyavanichi on the north coast of Perú. Hamful Algae News 47: 24-25.

Bakun A \& RH Parrish. 1982. Turbulence, transport, and pelagic fish in the California and Peru currents systems. CALCOFI Report 23: 99-112.

Baylón M, S Sánchez, V Bárenca, J López \& E Mamani. 2015. First record of potentially toxic dinoflagellate, Alexandrium minutum Halim 1960, from Peruvian coast. Revista Peruana de Biología 22: 113-118.

Carrit DE \& JH Carpenter. 1966. Comparison and evaluation of currently employed modifications of the Winkler method for determining dissolved oxygen in seawater; a NASCO report. Journal of Marine Research 24: 286-318.

Cushing DH. 1989. A difference in structure between ecosystems in strongly stratified waters and in those that are only weakly stratified. Journal of Plankton Research 11: 113.

Graco M, J Ledesma, G Flores \& M Girón. 2007. Nutrients, oxygen and biogeochemical processes in the Humboldt upwelling current system off Peru. Revista Peruana de Biología 14: 117-128.

Graco M, D Correa, W García \& M Sarmiento. 2016. Impactos del ENSO en la biogeoquímica del sistema de afloramiento frente a Perú central, febrero 2013-diciembre 2015. Boletín Trimestral Oceanográfico 2: 2-6.

Gu H, Z Luo, B Krock, M Witt \& U Tillmann. 2013. Morphology, phylogeny and azaspiracid profile of Azadinium poporum (Dinophyceae) from the China Sea. Harmful Algae 21/22: 64-75.

Hallegraeff GM. 2003. Harmful algal blooms: A global overview. In: Hallegraeff GM, D Anderson \& AD Cembella (eds). Manual on harmful marine microalgae, pp. 25-49. UNESCO, Paris.

Hallegraeff GM. 2014. Harmful algae and their toxins: Progress, paradoxes and paradigm shifts. In: Rossini GP (ed). Toxins and biologically active compounds from microalgae, pp. 320. CRC Press, Boca Raton.

Hernández-Becerril DU, SA Barón-Campis \& S EscobarMorales. 2012. A new record of Azadinium spinosum (Dinoflagellata) from the tropical Mexican Pacific. Revista de Biología Marina y Oceanografía 47: 553-557.

Holm-Hansen O, CJ Lorenzen, RW Holmes \& JDH Strickland. 1965. Fluorometric determination of chlorophyll. Journal du Conseil International pour 1'Exploration de la Mer 30:3-15.

IMARPE. 2014. Informe sobre la situación actual del stock norte-centro de la anchoveta peruana a octubre del 2014. Of. $\mathrm{N}^{\circ}$ PCD-100-522. 2014 PRODUCE /IMP, 44 pp. IMARPE, Callao.
Karlson B, C Cusack \& E Bresnan. 2010. Microscopic and molecular methods for quantitative phytoplankton analysis. IOC Manuals and Guides 55: 1-110. UNESCO, Paris

Kim JW, U Tillmann, NG Adams, B Krock, WL Stutts, JR Deeds, MS Han \& VL Trainer. 2017. Identification of Azadinium species and a new azaspiracid from Azadinium poporum in Puget Sound, Washington State, USA. Harmful Algae 68: 152-167.

Kremp A, P Tahvanainen, W Litaker, B Krock, S Suikkanen, CP Leaw \& C Tomas. 2014. Phylogenetic relationships, morphological variation, and toxin pattern in the Alexandrium ostenfeldii (Dinopyhceae) complex: implications for species boundaries and identities. Journal of Phycology 50: 81-100.

Krock B, U Tillmann, U John \& AD Cembella. 2009. Characterization of azaspiracids in plankton size-fractions and isolation of an azaspiracid-producing dinoflagellate from the North Sea. Harmful Algae 8: 254-263.

Krock B, U Tillmann, D Voß, BP Koch, R Salas, M Witt, E Potvin \& HJ Jeong. 2012. New azaspiracids in Amphidomataceae (Dinophyceae): proposed structures. Toxicon 60: 830-839.

López-Rivera A, K O'Callaghan, M Moriarty, D O'Driscoll, B Hamilton, M Lehane, KJ James \& A Furey. 2010. First evidence of azaspiracids (AZAs): A family of lipophilic polyether marine toxins in scallops (Argopecten purpuratus) and mussels (Mytilus chilensis) collected in two regions of Chile. Toxicon 55: 692-701.

Luo Z, H Gu, B Krock \& U Tillmann. 2013. Azadinium dalianense, a new dinoflagellate from the Yellow Sea, China. Phycologia 52: 625-636.

Luo Z, B Krock, KN Mertens, AM Price, RE Turner, NN Rabalais \& H Gu. 2016. Morphology, molecular phylogeny and azaspiracid profile of Azadinium poporum (Dinophyceae) from the Gulf of Mexico. Harmful Algae 55: 56-65.

Massucatto A, AL Siqueira-Pilotto \& MA Schramm. 2014. Investigação da presença de Azaspirácidos em recursos pesqueiros do Canal do Linguado. Seminário de Pesquisa, Extensão e Inovação do Instituto Federal Santa Catarina. <http://eventoscientificos.ifsc.edu.br/index.php/sepei/ sepei2014/paper/viewFile/407/398>

Ochoa N, O Gómez, S Sánchez \& E Delgado. 1999. Diversidad de diatomeas y dinoflagelados marinos del Perú. Boletín del Instituto del Mar del Perú 18: 1-14

Ochoa N, MH Taylor, S Purca \& E Ramos. 2010. Intra- and interannual variability of nearshore phytoplankton biovolume and community changes in the northern Humboldt Current system. Journal of Plankton Research 32: 843-855.

Okolodkov YB \& JD Dodge. 1995. Redescription of the planktonic dinoflagellate Peridiniella danica (Paulsen) comb. nov. and its distribution in the N.E. Atlantic. European Journal of Phycology 30: 299-306.

Potvin É, HJ Jeong, NST Kang, U Tillmann \& B Krock. 2012. First report of the photosynthetic dinoflagellate genus Azadinium in the Pacific Ocean: Morphology and molecular characterization of Azadinium cf. poporum. Journal of Eukaryotic Microbiology 59: 145-156. 
Potvin É, YJ Hwang, YD Yoo, JS Kim \& HJ Jeong. 2013. Feeding by heterotrophic protists and copepods on the photosynthetic dinoflagellate Azadinium cf. poporum from western Korean waters. Aquatic Microbial Ecology 68: 143158.

Rojas de Mendiola B. 1979. Red tides along the Peruvian coast. In: Taylor DL \& HH Seliger (eds). Toxic dinoflagellate blooms, pp. 183-190. Elsevier, New York.

Rossi R, C Dell'Aversano, B Krock, P Ciminiello, I Percopo, U Tillmann, V Soprano \& A Zingone. 2017. Mediterranean Azadinium dexteroporum (Dinophyceae) produces AZA-35 and six novel azaspiracids: a structural study by a multi-platform mass spectrometry approach. Analytical and Bioanalytical Chemistry 409: 1121-1134.

Salas R, U Tillmann, U John, J Kilcoyne, A Burson, C Cantwell, P Hess, T Jauffrais \& J Silke. 2011. The role of Azadinium spinosum (Dinophyceae) in the production of Azaspiracid Shellfish Poisoning in mussels. Harmful Algae 10:774-783.

Sánchez G. 2000. Peru. In: Sheppard C (ed). Seas at the Millennium: An environmental evaluation, pp. 687-697. Pergamon, Amsterdam.

Sánchez S \& E Delgado. 1996. Mareas rojas en el área del Callao (12 $\left.{ }^{\circ} \mathrm{S}\right)$ 1980-1995. Informe Progresivo, Instituto del Mar del Perú 44: 19-37.

Satake M, K Ofuji, K James, A Furey \& T Yasumoto. 1998. New toxic events caused by Irish mussels. In: Reguera B, J Blanco, ML Fernández \& T Wyatt (eds). Harmful Algae, pp. 468-469. Xunta de Galicia, International Oceanographic Commission of UNESCO, Santiago de Compostela.

Smayda TJ. 1997. Harmful algal blooms: their ecophysiology and general relevance to phytoplankton blooms in the sea. Limnology and Oceanography 42: 1137-1153.

Smith KF, L Rhodes, DT Harwood, J Adamson, C Moisan, R Munday \& U Tillmann. 2016. Detection of Azadinium poporum in New Zealand: the use of molecular tools to assist with species isolations. Journal of Applied Phycology 28: 11251132.

Strickland J \& T Parsons. 1972. Practical handbook of seawater analysis. Fisheries Research Board of Canada, Bulletin 167: 1-311.

Tillmann U \& R Akselman. 2016. Revisiting the 1991 algal bloom in shelf waters off Argentina: Azadinium luciferelloides sp. nov. (Amphidomataceae, Dinophyceae) as the causative species in a diverse community of other amphidomataceans. Phycological Research 64: 160-175.

Tillmann U, M Elbrächter, B Krock, U John \& A Cembella. 2009. Azadinium spinosum gen. et sp. nov. (Dinophyceae) identified as a primary producer of azaspiracid toxins. European Journal of Phycology 44: 63-79.
Tillmann U, M Elbrächter, U John, B Krock \& A Cembella. 2010. Azadinium obesum (Dinophyceae), a new nontoxic species in the genus that can produce azaspiracid toxins. Phycologia 49: 169-182.

Tillmann U, S Söhner, E Nézan \& B Krock. 2012a. First record of Azadinium from the Shetland Islands including the description of A. polongum sp. nov. Harmful Algae 20: 142155.

Tillmann U, R Salas, M Gottschling, B Krock, D O'Driscoll \& M Elbrächter. 2012b. Amphidoma languida sp. nov. (Dinophyceae) reveals a close relationship between Amphidoma and Azadinium. Protist 163: 701-719.

Tillmann U, R Salas, T Jauffrais, P Hess \& J Silke. 2014a. AZA: The producing organisms, Biology and trophic transfer. In: Botana LM (ed). Seafood and freshwater Toxins, pp. 773-798. CRC Press, Boca Raton.

Tillmann U, M Gottschling, E Nézan, B Krock \& G Bilien. 2014b. Morphological and molecular characterization of three new Azadinium species (Amphidomataceae, Dinophyceae) from the Irminger Sea. Protist 165: 417-444.

Tillmann U, M Borel, F Barrera, R Lara, B Krock, G Almandoz \& N Trefault. 2016. Azadinium poporum (Dinophyceae) from the South Atlantic off the Argentinean coast produce AZA-2. Harmful Algae 51: 40-55.

Tillmann U, N Trefault, B Krock, G Parada-Pozo, R De la Iglesia \& M Vásquez. 2017. Identification of Azadinium poporum (Dinophyceae) in the Southeast Pacific: morphology, molecular phylogeny, and azaspiracid profile characterization. Journal of Plankton Research 39: 350-367.

Trainer VL, GC Pitcher, B Reguera \& TJ Smayda. 2010. The distribution and impacts of harmful algal bloom species in eastern boundary upwelling systems. Progress in Oceanography 85: 33-52.

Trainer VL, L Moore, BD Bill, NG Adams, $N$ Harrington, J Borchert, DAM Da Silva \& BTL Eberhard. 2013. Diarrhetic shellfish toxins and other lipophilic toxins of human health concern in Washington State. Marine Drugs 11: 18151835.

Turner AD \& AB Goya. 2015. Occurrence and profiles of lipophilic toxins in shellfish harvested from Argentina. Toxicon 102: 32-42.

UNESCO. 1983. Chemical methods for use in marine environmental monitoring. Intergovernmental Oceanographic Comission. IOC Manuals and Guides 12: 1-53.

Vera G, S Fraga, JM Franco \& G Sánchez. 1999. First record in Peru of the dinoflagellate Alexandrium affine Inoue and Fukuyo. Informe Progresivo, Instituto del Mar del Perú 105: 3-12.

Zuta S \& O Guillén. 1970. Oceanografía de las aguas costeras del Perú. Boletín Instituto del Mar del Perú 2: 157-324. 
Supplement 1 Phytoplankton species and abundances, February 2014 (for location of stationssee Fig 1)/ Especies de fitoplancton y abundancias celulares, febrero 2014 (para localización de estaciones vea Fig. 1)

\begin{tabular}{|c|c|c|c|c|c|c|c|c|c|c|c|c|c|c|c|c|}
\hline \multirow{2}{*}{$\begin{array}{c}\text { Station } \\
\text { Depth (m) }\end{array}$} & \multicolumn{2}{|c|}{1} & \multicolumn{2}{|c|}{2} & \multicolumn{2}{|c|}{3} & \multicolumn{2}{|c|}{4} & \multicolumn{2}{|c|}{7} & \multicolumn{2}{|c|}{8} & \multicolumn{2}{|c|}{9} & \multicolumn{2}{|c|}{11} \\
\hline & 0 & 10 & 0 & 10 & 0 & 10 & 0 & 10 & 0 & 10 & 0 & 10 & 0 & 10 & 0 & 10 \\
\hline Sea Surface temperature $\left({ }^{\circ} \mathrm{C}\right)$ & 21.0 & & 20.8 & & 20.5 & & 19.8 & & 18.0 & & 19.4 & & 19.6 & & 19.2 & \\
\hline Plankton volume $\left(\mathrm{mL} \mathrm{m}^{-3}\right)$ & 0.166 & n.d. & 0.483 & n.d. & n.d. & n.d & 0.030 & n.d. & 0.664 & n.d. & 0.709 & n.d. & 0.377 & n.d. & 0.573 & n.d. \\
\hline Chlorophyll $\left(\mu \mathrm{g} \mathrm{L} \mathrm{L}^{-1}\right)$ & 0.57 & 0.13 & 2.02 & 0.18 & 2.58 & 0.05 & 1.89 & 0.05 & 0.23 & 0.18 & 1.37 & 0.46 & 1.32 & 0.10 & 1.24 & 0.70 \\
\hline \multicolumn{17}{|l|}{ Diatoms (cells L-1) } \\
\hline Achnanthes longipes & 0 & 0 & 0 & 0 & 0 & 0 & 0 & 0 & 0 & 0 & 140 & 0 & 0 & 0 & 0 & 0 \\
\hline Actinocyclus sp. & 0 & 0 & 0 & 0 & 0 & 440 & 40 & 2,000 & 940 & 3,480 & 0 & 3,400 & 0 & 3,760 & 0 & 140 \\
\hline Actinoptychus senarius & 0 & 80 & 0 & 0 & 0 & 0 & 140 & 0 & 40 & 0 & 0 & 0 & 0 & 40 & 0 & 0 \\
\hline Amphiprora sp. & 580 & 16,360 & 560 & 0 & 2,520 & 480 & 48,680 & 620 & 80 & 1,760 & 360 & 400 & 440 & 200 & 20 & 200 \\
\hline Amphora sp. & 1,720 & 300 & 640 & 1,760 & 2,080 & 400 & 2,580 & 960 & 240 & 320 & 980 & 80 & 280 & 20 & 240 & 0 \\
\hline Cerataulina pelagica & 0 & 0 & 0 & 200 & 6,080 & 0 & 0 & 0 & 0 & 0 & 0 & 0 & 0 & 0 & 0 & 0 \\
\hline Chaetoceros affinis & 100 & 0 & 1,720 & 1,640 & 0 & 0 & 12,120 & 960 & 0 & 240 & 2,180 & 240 & 300 & 0 & 200 & 680 \\
\hline Chaetoceros compressus & 0 & 0 & 0 & 0 & 320 & 0 & 0 & 0 & 0 & 0 & 0 & 0 & 0 & 0 & 0 & 0 \\
\hline Chaetoceros danicus & 0 & 0 & 0 & 0 & 40 & 0 & 0 & 0 & 0 & 0 & 0 & 0 & 0 & 0 & 0 & 0 \\
\hline Chaetoceros debilis & 0 & 0 & 0 & 680 & 0 & 0 & 0 & 0 & 0 & 0 & 0 & 0 & 0 & 0 & 0 & 0 \\
\hline Chaetoceros didymus & 0 & 140 & 0 & 0 & 0 & 0 & 0 & 560 & 0 & 0 & 520 & 0 & 640 & 0 & 0 & 0 \\
\hline Chaetoceros lorenziamus & 0 & 0 & 0 & 0 & 0 & 0 & 0 & 0 & 0 & 0 & 460 & 0 & 0 & 120 & 0 & 0 \\
\hline Chaetoceros sp. & 0 & 0 & 7,000 & 0 & 0 & 0 & 0 & 0 & 0 & 0 & 0 & 0 & 0 & 0 & 0 & 0 \\
\hline Coscinodiscus centralis & 0 & 0 & 0 & 0 & 0 & 0 & 0 & 0 & 0 & 0 & 0 & 0 & 0 & 40 & 60 & 0 \\
\hline Coscinodiscus granii & 0 & 0 & 0 & 0 & 0 & 0 & 0 & 40 & 0 & 0 & 20 & 100 & 0 & 20 & 40 & 0 \\
\hline Coscinodiscus perforatus & 0 & 40 & 0 & 0 & 20 & 0 & 40 & 60 & 120 & 0 & 500 & 320 & 320 & 420 & 740 & 120 \\
\hline Cyclotella sp. & 100 & 0 & 0 & 0 & 0 & 0 & 80 & 0 & 480 & 0 & 0 & 380 & 220 & 80 & 0 & 0 \\
\hline Cylindroteca closterium & 103,000 & 0 & 1,120 & 720 & 37,000 & 360 & 32,400 & 2,400 & 160 & 80 & 1,920 & 320 & 1,600 & 0 & 1,440 & 300 \\
\hline Dactyliosolen fragilissimus & 1,420 & 0 & 0 & 40 & 0 & 0 & 7,040 & 0 & 0 & 0 & 660 & 0 & 0 & 0 & 40 & 0 \\
\hline Detonula pumila & 240 & 0 & 0 & 0 & 0 & 0 & 0 & 0 & 0 & 0 & 0 & 0 & 0 & 0 & 0 & 0 \\
\hline Ditylum brightwellii & 680 & 80 & 160 & 320 & 1,240 & 320 & 5,200 & 340 & 80 & 0 & 180 & 20 & 0 & 0 & 0 & 0 \\
\hline Entomoneis alata v. alata & 640 & 20 & 1,560 & 8,000 & 1,040 & 480 & 5,380 & 1,100 & 220 & 960 & 140 & 320 & 60 & 400 & 20 & 440 \\
\hline Eucampia zoodiacus & 1,560 & 0 & 80 & 500 & 0 & 0 & 14,040 & 1,040 & 0 & 8,080 & 6,320 & 28,100 & 6,340 & 0 & 0 & 0 \\
\hline Fragilariopsis doliolus & 0 & 0 & 200 & 0 & 0 & 320 & 80 & 23,200 & 1,500 & 560 & 80 & 0 & 100 & 120 & 0 & 6,020 \\
\hline Guinardia delicatula & 0 & 0 & 0 & 240 & 0 & 0 & 0 & 0 & 0 & 0 & 0 & 0 & 300 & 0 & 0 & 0 \\
\hline
\end{tabular}


Supplement 1 Continued / Continuació

Phytoplankton species and abundances, February 2014 (for location of stations see Fig. 1) / Especies de fitoplancton y abundancias celulares, febrero 2014 (para localización de estaciones vea Fig. 1)

\begin{tabular}{|c|c|c|c|c|c|c|c|c|c|c|c|c|c|c|c|c|}
\hline \multirow{2}{*}{$\begin{array}{c}\text { Station } \\
\text { Depth (m) }\end{array}$} & \multicolumn{2}{|c|}{1} & \multicolumn{2}{|c|}{2} & \multicolumn{2}{|c|}{3} & \multicolumn{2}{|c|}{4} & \multicolumn{2}{|c|}{7} & \multicolumn{2}{|c|}{8} & \multicolumn{2}{|c|}{9} & \multicolumn{2}{|c|}{11} \\
\hline & 0 & 10 & 0 & 10 & 0 & 10 & 0 & 10 & 0 & 10 & 0 & 10 & 0 & 10 & 0 & 10 \\
\hline Guinardia striata & 140 & 0 & 0 & 0 & 240 & 60 & 300 & 0 & 140 & 320 & 11,920 & 0 & 2,600 & 0 & 40 & 220 \\
\hline Rhizosolenia robusta & 0 & 0 & 0 & 0 & 0 & 0 & 0 & 20 & 0 & 0 & 0 & 0 & 0 & 0 & 0 & 0 \\
\hline Gyrosigma sp. & 20 & 0 & 0 & 0 & 40 & 0 & 0 & 40 & 0 & 0 & 0 & 0 & 0 & 0 & 0 & 0 \\
\hline Hemiaulus sinensis & 0 & 0 & 0 & 0 & 0 & 280 & 1,080 & 0 & 0 & 0 & 500 & 1,120 & 0 & 0 & 0 & 0 \\
\hline Lauderia annulata & 0 & 0 & 0 & 0 & 0 & 0 & 1,280 & 0 & 0 & 0 & 100 & 0 & 60 & 0 & 300 & 0 \\
\hline Leptocylindrus danicus & 409,000 & 60 & 16,520 & 0 & 74,000 & 0 & 264,000 & 940 & 80 & 0 & 4,120 & 0 & 1,320 & 0 & 1,240 & 0 \\
\hline Leptocylindrus minimus & 0 & 0 & 0 & 0 & 0 & 0 & 201,000 & 0 & 0 & 0 & 0 & 0 & 0 & 0 & 0 & 0 \\
\hline Licmophora abbreviata & 0 & 0 & 0 & 0 & 0 & 0 & 0 & 0 & 0 & 0 & 0 & 0 & 0 & 20 & 0 & 0 \\
\hline Lithodesmium undulatum & 0 & 240 & 0 & 1,040 & 53,000 & 600 & 4,620 & 320 & 0 & 0 & 2,260 & 2,240 & 840 & 180 & 740 & 580 \\
\hline Navicula sp. & 0 & 0 & 0 & 2,000 & 0 & 0 & 0 & 0 & 0 & 0 & 0 & 0 & 0 & 0 & 0 & 220 \\
\hline Odontella aurita & 0 & 240 & 0 & 0 & 0 & 0 & 0 & 0 & 0 & 160 & 0 & 2,900 & 0 & 320 & 0 & 0 \\
\hline Planktoniella sol & 0 & 0 & 40 & 0 & 0 & 0 & 0 & 80 & 260 & 160 & 100 & 40 & 20 & 160 & 20 & 140 \\
\hline Pennatae & 0 & 400 & 0 & 480 & 0 & 320 & 1,000 & 0 & 1,000 & 0 & 3,000 & 0 & 0 & 1,000 & 0 & 0 \\
\hline Pleurosigma sp. & 0 & 140 & 120 & 40 & 40 & 360 & 40 & 760 & 640 & 1,840 & 40 & 2,380 & 20 & 700 & 0 & 240 \\
\hline Proboscia alata & 20 & 0 & 0 & 0 & 0 & 0 & 40 & 40 & 0 & 0 & 180 & 0 & 0 & 0 & 0 & 0 \\
\hline Proboscia alata var indica & 0 & 0 & 0 & 0 & 0 & 0 & 0 & 0 & 0 & 80 & 0 & 0 & 0 & 0 & 0 & 0 \\
\hline $\begin{array}{l}\text { Pseudo-nitzschia seriata } \\
\text { (complejo) }\end{array}$ & 0 & 0 & 0 & 0 & 0 & 0 & 180 & 0 & 0 & 0 & 0 & 0 & 0 & 0 & 0 & 0 \\
\hline Pseudosolenia calcar-avis & 0 & 0 & 0 & 0 & 0 & 0 & 0 & 40 & 0 & 0 & 20 & 0 & 0 & 0 & 0 & 0 \\
\hline Rhizosolenia chunii & 0 & 0 & 0 & 0 & 0 & 0 & 200 & 0 & 0 & 0 & 0 & 0 & 0 & 0 & 0 & 0 \\
\hline Rhizosolenia robusta & 0 & 0 & 0 & 40 & 0 & 0 & 0 & 0 & 0 & 0 & 40 & 0 & 20 & 0 & 0 & 0 \\
\hline Rhizosolenia styliformis & 0 & 0 & 0 & 0 & 0 & 0 & 40 & 0 & 0 & 0 & 0 & 0 & 0 & 0 & 0 & 0 \\
\hline Roperia tesselata & 0 & 0 & 0 & 0 & 0 & 0 & 0 & 0 & 0 & 0 & 0 & 60 & 0 & 0 & 0 & 0 \\
\hline Skeletonema costatum & $1,201,000$ & 79,000 & 5,440 & 35,240 & 556,000 & 9,600 & 354,000 & 2,520 & 0 & 320 & 3,480 & 0 & 0 & 0 & 0 & 460 \\
\hline Thalassionema frauenfeldii & 0 & 120 & 0 & 0 & 1,280 & 0 & 160 & 0 & 0 & 0 & 60 & 0 & 140 & 0 & 0 & 0 \\
\hline Thalassionema nitzschioides & 11,720 & 2,260 & 7,760 & 23,840 & 105,000 & 3,720 & 8,040 & 6,680 & 8,040 & 7,040 & 133,000 & 3,560 & 125,000 & 2,300 & 123,000 & 14,360 \\
\hline Thalassiosira angulata & 0 & 0 & 0 & 160 & 0 & 0 & 0 & 0 & 0 & 880 & 0 & 20 & 0 & 0 & 0 & 180 \\
\hline Thalassiosira anguste-lineata & 560 & 0 & 0 & 0 & 0 & 0 & 2,680 & 0 & 3,500 & 520 & 1,440 & 42,200 & 620 & 7,640 & 760 & 180 \\
\hline Thalassiosira mendiolana & 0 & 0 & 0 & 0 & 120 & 0 & 0 & 0 & 0 & 29,120 & 0 & 2,040 & 0 & 0 & 0 & 120 \\
\hline Thalassiosira subtilis & 372,000 & 8,640 & 36,000 & 143,000 & 204,000 & 11,600 & 2,250 & 115,000 & 34,360 & 6,760 & 32,480 & 7,460 & 11,800 & 5,700 & 7.760 & 251,000 \\
\hline Thalassiosira sp. & 400 & 0 & 0 & 0 & 0 & 0 & 0 & 0 & 0 & 21,280 & 0 & 0 & 0 & 420 & 0 & 324,000 \\
\hline Thalassiotrix longissima & 20 & 20 & 0 & 0 & 0 & 0 & 120 & 20 & 0 & 0 & 0 & 0 & 0 & 0 & 0 & 0 \\
\hline Total diatoms & $2,104,920$ & 108,140 & 78,920 & 219,240 & $1,044,060$ & 29,340 & 968,850 & 159,740 & 51,880 & 83,960 & 207,200 & 97,700 & 153,040 & 23,660 & 136,660 & 599,600 \\
\hline
\end{tabular}


Supplement 1 Continued / Continuación

Phytoplankton species and abundances, February 2014 (for location of stations see Fig 1) / Especies de fitoplancton y abundancias celulares, febrero 2014 (para localización de estaciones vea Fig. 1)

\begin{tabular}{|c|c|c|c|c|c|c|c|c|c|c|c|c|c|c|c|c|}
\hline \multirow{2}{*}{$\begin{array}{c}\text { Station } \\
\text { Depth }(\mathrm{m})\end{array}$} & \multicolumn{2}{|l|}{1} & \multicolumn{2}{|c|}{2} & \multicolumn{2}{|c|}{3} & \multicolumn{2}{|c|}{4} & \multicolumn{2}{|c|}{7} & \multicolumn{2}{|c|}{8} & \multicolumn{2}{|c|}{9} & \multicolumn{2}{|c|}{11} \\
\hline & 0 & 10 & 0 & 10 & 0 & 10 & 0 & 10 & 0 & 10 & 0 & 10 & 0 & 10 & 0 & 10 \\
\hline \multicolumn{17}{|l|}{ Dinoflagellates (cells L $\mathrm{L}^{-1}$ ) } \\
\hline Azadinium sp. & 6,000 & 1,380 & 664,000 & 0 & $1,056,000$ & 1,000 & 0 & 7,000 & 0 & 5,440 & 0 & 9,000 & 0 & 0 & 0 & 0 \\
\hline Tripos azoricum & 0 & 0 & 0 & 0 & 0 & 0 & 0 & 20 & 0 & 0 & 0 & 0 & 0 & 0 & 0 & 0 \\
\hline Tripos buceros & 200 & 100 & 40 & 1,200 & 120 & 0 & 160 & 0 & 20 & 640 & 80 & 1,820 & 0 & 340 & 0 & 0 \\
\hline Tripos dens & 0 & 0 & 40 & 0 & 160 & 0 & 20 & 0 & 0 & 0 & 0 & 0 & 0 & 0 & 0 & 200 \\
\hline Tripos furca & 0 & 0 & 80 & 0 & 4,160 & 0 & 820 & 220 & 1,480 & 1,320 & 180 & 40 & 140 & 20 & 80 & 4,840 \\
\hline Tripos fusus var. fusus & 0 & 0 & 0 & 20 & 0 & 0 & 0 & 160 & 380 & 240 & 0 & 0 & 0 & 0 & 0 & 220 \\
\hline Tripos sp. (atípico) & 0 & 0 & 0 & 0 & 0 & 40 & 0 & 0 & 0 & 0 & 0 & 0 & 0 & 0 & 0 & 0 \\
\hline Dinophysis acuminata & 0 & 0 & 0 & 0 & 80 & 0 & 40 & 500 & 40 & 400 & 0 & 60 & 0 & 100 & 0 & 100 \\
\hline Dinophysis caudata & 0 & 0 & 40 & 80 & 640 & 0 & 120 & 2,000 & 1,400 & 840 & 20 & 260 & 20 & 60 & 0 & 4,140 \\
\hline Dinophysis rotundata & 40 & 0 & 0 & 0 & 0 & 0 & 20 & 20 & 40 & 80 & 0 & 0 & 0 & 80 & 0 & 0 \\
\hline Dinophysis tripos & 0 & 0 & 0 & 0 & 0 & 0 & 0 & 20 & 0 & 0 & 0 & 0 & 0 & 0 & 0 & 40 \\
\hline Diplopeltopsis minor & 860 & 0 & 0 & 0 & 0 & 0 & 60 & 0 & 480 & 0 & 0 & 0 & 200 & 0 & 180 & 0 \\
\hline Gonyaulax spinifera & 0 & 0 & 0 & 0 & 80 & 0 & 0 & 0 & 0 & 0 & 0 & 0 & 0 & 0 & 0 & 0 \\
\hline Gymnodiales spp. & 60 & 0 & 43,000 & 92,000 & 19,000 & 1,560 & 2,000 & 0 & 0 & 0 & 0 & 540 & 0 & 6,000 & 0 & 3,500 \\
\hline Gymnodinium lohmanni & 100 & 80 & 520 & 360 & 320 & 1,280 & 160 & 60 & 0 & 0 & 0 & 160 & 0 & 0 & 0 & 0 \\
\hline Gymnodinium sp. & 0 & 0 & 0 & 5,200 & 0 & 17,680 & 0 & 0 & 0 & 0 & 0 & 0 & 0 & 0 & 0 & 0 \\
\hline Karlodinium sp. & 0 & 0 & 0 & 0 & 0 & 0 & 0 & 0 & 0 & 6,320 & 0 & 0 & 0 & 0 & 0 & 0 \\
\hline Oxyphysis oxytoxoides & 0 & 0 & 40 & 0 & 160 & 0 & 0 & 140 & 0 & 80 & 0 & 0 & 0 & 0 & 0 & 0 \\
\hline Podolampas palmipes & 0 & 0 & 0 & 0 & 0 & 0 & 0 & 40 & 0 & 0 & 0 & 20 & 0 & 0 & 0 & 0 \\
\hline Pronoctiluca pelagica & 0 & 0 & 0 & 0 & 0 & 120 & 0 & 0 & 0 & 0 & 0 & 0 & 0 & 0 & 0 & 0 \\
\hline Prorocentrum gracile & 2,160 & 0 & 3,680 & 0 & 5,360 & 0 & 520 & 40 & 20 & 0 & 0 & 0 & 60 & 0 & 20 & 0 \\
\hline Prorocentrum cf. dentatum & 40 & 0 & 0 & 0 & 0 & 0 & 0 & 0 & 0 & 0 & 0 & 0 & 0 & 0 & 0 & 0 \\
\hline Prorocentrum micans & 860 & 20 & 2,360 & 0 & 19,840 & 0 & 9,480 & 1,740 & 4,400 & 560 & 20 & 120 & 240 & 20 & 2,460 & 120 \\
\hline Prorocentrum cordatum & $11,208,000$ & 0 & 63,000 & 0 & 104,000 & 120 & 0 & 0 & 0 & 0 & 0 & 0 & 0 & 0 & 0 & 0 \\
\hline Protoperidinium $\mathrm{sp}$. & 2,000 & 0 & 0 & 0 & 0 & 0 & 0 & 0 & 0 & 0 & 0 & 0 & 0 & 0 & 0 & 0 \\
\hline Protoperidinium conicoides & 20 & 0 & 0 & 0 & 0 & 0 & 0 & 0 & 60 & 0 & 0 & 0 & 0 & 0 & 0 & 0 \\
\hline Protoperidinium conicum & 260 & 20 & 0 & 0 & 600 & 0 & 100 & 80 & 40 & 0 & 20 & 20 & 0 & 160 & 0 & 480 \\
\hline Protoperidinium crassipes & 0 & 0 & 40 & 0 & 80 & 0 & 0 & 200 & 0 & 720 & 0 & 0 & 0 & 20 & 0 & 180 \\
\hline Protoperidinium depressum & 20 & 0 & 80 & 0 & 80 & 0 & 140 & 0 & 240 & 0 & 0 & 0 & 0 & 20 & 0 & 60 \\
\hline Protoperidinium excentricum & 0 & 0 & 40 & 0 & 80 & 0 & 140 & 80 & 40 & 80 & 0 & 0 & 0 & 20 & 0 & 180 \\
\hline Protoperidinium leonis & 20 & 0 & 40 & 20 & 200 & 0 & 20 & 0 & 0 & 0 & 0 & 0 & 0 & 0 & 0 & 0 \\
\hline Protoperidinium longispinum & 60 & 0 & 40 & 120 & 40 & 0 & 20 & 480 & 160 & 240 & 20 & 20 & 40 & 100 & 20 & 220 \\
\hline Protoperidinium mendiolae & 0 & 20 & 0 & 0 & 480 & 0 & 0 & 0 & 0 & 0 & 0 & 0 & 0 & 0 & 0 & 0 \\
\hline
\end{tabular}


Supplement 1. Continued / Continuación

Phytoplankton species and abundances, February 2014 (for location of stations see Fig. 1) / Especies de fitoplancton y abundancias celulares, febrero 2014 (para localización de estaciones vea Fig. 1)

\begin{tabular}{|c|c|c|c|c|c|c|c|c|c|c|c|c|c|c|c|c|}
\hline \multirow{2}{*}{$\begin{array}{c}\text { Station } \\
\text { Depth (m) }\end{array}$} & \multicolumn{2}{|c|}{1} & \multicolumn{2}{|c|}{2} & \multicolumn{2}{|c|}{3} & \multicolumn{2}{|c|}{4} & \multicolumn{2}{|c|}{7} & \multicolumn{2}{|c|}{8} & \multicolumn{2}{|c|}{9} & \multicolumn{2}{|c|}{11} \\
\hline & 0 & 10 & 0 & 10 & 0 & 10 & 0 & 10 & 0 & 10 & 0 & 10 & 0 & 10 & 0 & 10 \\
\hline Protoperidinium minutum & 0 & 0 & 0 & 20 & 0 & 0 & 0 & 20 & 0 & 0 & 0 & 0 & 0 & 0 & 0 & 0 \\
\hline Protoperidinium oblongum & 40 & 0 & 0 & 0 & 0 & 0 & 160 & 0 & 20 & 0 & 0 & 0 & 0 & 0 & 0 & 0 \\
\hline Protoperidinium obtusum & 20 & 0 & 40 & 0 & 120 & 0 & 60 & 20 & 60 & 0 & 20 & 0 & 0 & 20 & 0 & 100 \\
\hline Protoperidinium осеапicum & 40 & 0 & 0 & 0 & 0 & 0 & 20 & 0 & 0 & 80 & 0 & 0 & 40 & 20 & 0 & 0 \\
\hline Protoperidinium pellucidum & 20 & 0 & 40 & 0 & 80 & 0 & 240 & 60 & 680 & 0 & 0 & 0 & 200 & 0 & 100 & 200 \\
\hline Protoperidinium pentagonum & 0 & 0 & 0 & 0 & 0 & 0 & 0 & 0 & 0 & 80 & 0 & 0 & 0 & 0 & 0 & 80 \\
\hline Protoperidinium peruviamum & 0 & 0 & 0 & 0 & 0 & 0 & 0 & 0 & 0 & 80 & 0 & 0 & 0 & 0 & 0 & 0 \\
\hline Protoperidinium steinii & 0 & 0 & 0 & 0 & 0 & 0 & 0 & 0 & 0 & 0 & 0 & 0 & 0 & 0 & 0 & 100 \\
\hline Scrippsiella trochoidea & 260 & 0 & 80 & 240 & 320 & 0 & 240 & 1,180 & 6,480 & 0 & 0 & 0 & 0 & 20 & 0 & 120 \\
\hline Pyrocystis elegans & 40 & 0 & 0 & 0 & 160 & 0 & 40 & 20 & 20 & 0 & 0 & 0 & 0 & 0 & 0 & 20 \\
\hline Pyrophacus horologicum & 20 & 0 & 0 & 80 & 120 & 0 & 160 & 40 & 80 & 0 & 40 & 0 & 0 & 0 & 0 & 0 \\
\hline Total dinoflagellates & $1,1221,140$ & 1,620 & 777,200 & 99,340 & $1,212,280$ & 21,800 & 14,740 & 14,140 & 16,140 & 17,200 & 400 & 12,060 & 940 & 7,000 & 2,860 & 14,900 \\
\hline \multicolumn{17}{|l|}{ Other flagellates (cell $\mathrm{L}^{-1}$ ) } \\
\hline Dictyocha fibula & 2,540 & 380 & 560 & 400 & 640 & 1,240 & 320 & 10,120 & 41,000 & 5,040 & 60 & 500 & 180 & 3,840 & 140 & 520 \\
\hline Octactis octonaria & 0 & 0 & 0 & 0 & 0 & 0 & 0 & 20 & 60 & 400 & 0 & 0 & 0 & 80 & 0 & 160 \\
\hline Emiliania huxleyi & 0 & 0 & 23,000 & 0 & 0 & 0 & 0 & 0 & 0 & 0 & 0 & 0 & 0 & 0 & 0 & 0 \\
\hline Eutreptiella gymnastica & 180 & 0 & 80 & 0 & 0 & 0 & 520 & 0 & 0 & 0 & 0 & 40 & 40 & 80 & 4,680 & 220 \\
\hline Leucocryptos marina & 0 & 0 & 0 & 8,000 & 24,000 & 0 & 0 & 2,000 & 4,000 & 2,000 & 0 & 0 & 0 & 0 & 0 & 1,000 \\
\hline Flagellates (not determined) & $2,342,000$ & 46,000 & 13,130 & 212,000 & 940,000 & 136,000 & $5,025,000$ & 37,000 & 9,000 & 340,000 & $1,968,000$ & 121,000 & $2,752,000$ & 72,000 & $7,515,000$ & 84,500 \\
\hline $\begin{array}{l}\text { TOTAL other flagellates } \\
\text { (cells } \mathrm{L}^{-1} \text { ) }\end{array}$ & $2,344,720$ & 46,380 & 36,690 & 220,400 & 964,640 & 137,240 & $5,025,840$ & 49,120 & 54,060 & 347,440 & $1,968,060$ & 121,540 & $2,752,220$ & 76,000 & $7,519,820$ & 86,400 \\
\hline $\begin{array}{l}\text { Total phytoplankton } \\
\text { (cells } \mathrm{L}^{-1} \text { ) }\end{array}$ & $15,670,780$ & 156,140 & 892,890 & 539,680 & $3,220,980$ & 188,380 & $6,009,430$ & 223,020 & 122,080 & 448,600 & $2,175,660$ & $2,313,00$ & $2,906,200$ & 106,660 & $7,659,340$ & 700,900 \\
\hline
\end{tabular}

